This PDF is a simplified version of the original article published in Internet Archaeology. Enlarged images, and interactive features which support this publication can be found in the original version online. All links also go to the online version.

Please cite this as: Leivers, M. 2021 The Army Basing Programme, Stonehenge and the Emergence of the Sacred Landscape of Wessex, Internet Archaeology 56. https://doi.org/10.11141/ia.56.2

\title{
The Army Basing Programme, Stonehenge and the Emergence of the Sacred Landscape of Wessex
}

Matt Leivers

Recent excavations for the Army Basing Programme on the periphery of the Stonehenge World Heritage Site have revealed extensive evidence of Early, Middle and Late Neolithic and Early Bronze Age activity, including a causewayed enclosure, burials, occupation, pit groups, henges, post alignments and circles. Several of these either incorporate or refer to features of the landscape such as solution hollows, dry valleys, hilltops and rivers, as well as to astronomical phenomena. An appraisal of this evidence alongside other recent programmes of research around Stonehenge suggest an accreting pattern of development of this landscape that begins in the 38th century BC, and which throws new light on the location and meaning of several of the ceremonial earthworks, including Stonehenge itself.

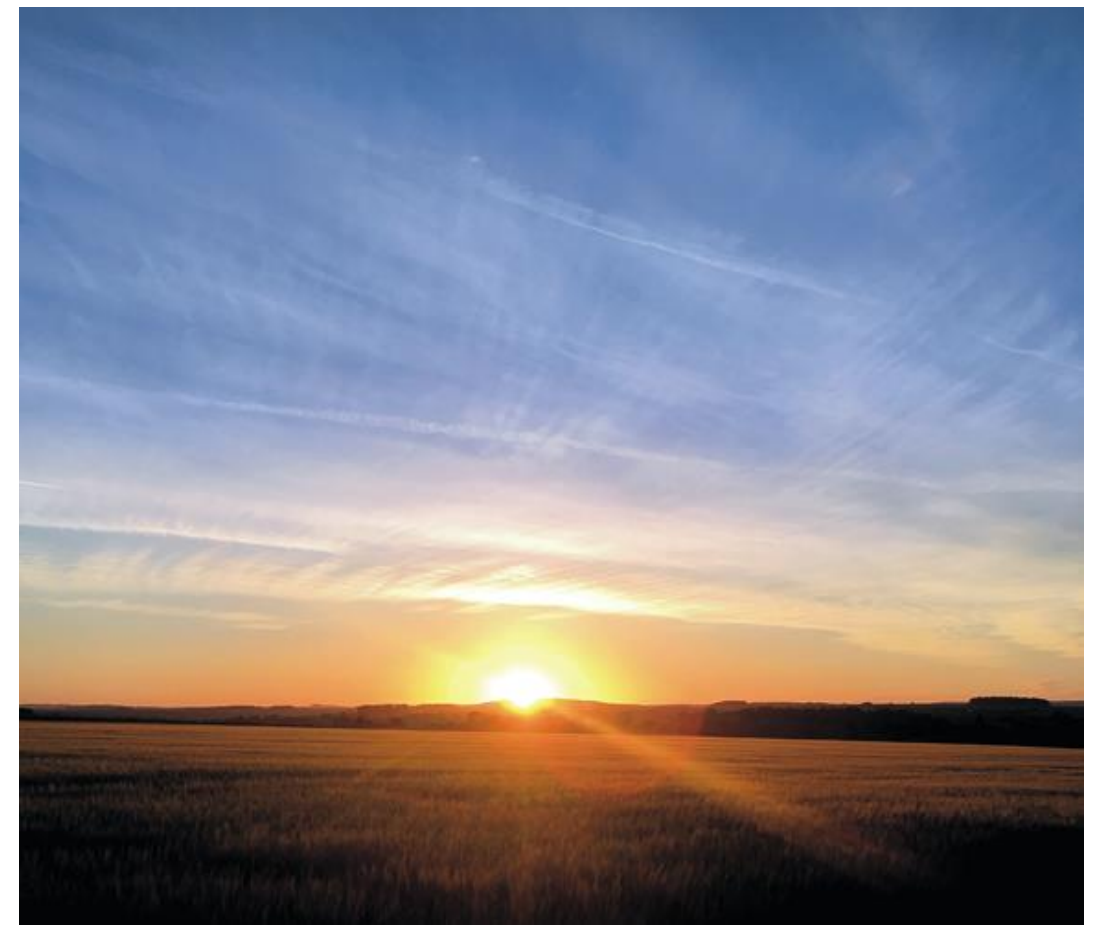

The sunrise from the Lark Hill causewayed enclosure 


\section{Introduction}

A recent programme of survey and excavation carried out by Wessex Archaeology as part of the Ministry of Defence's Army Basing Programme revealed a wealth of archaeological remains including a causewayed enclosure, henges, pits and burials. These results have demonstrated that some of the key relationships and foundational principles of the Stonehenge landscape pre-date the earliest phases of Stonehenge itself by at least 600 years, and that the development of the ceremonial landscape was an intermittent but continuous process of working and reworking over millennia, away from, as well as at, Stonehenge.

Throughout this article, Lark Hill refers to the landscape feature and any archaeology discovered on it, Larkhill to the military garrison town.

\subsection{The Army Basing Programme}

Aspire Defence, Lovell Partnerships and WYG commissioned Wessex Archaeology on behalf of Defence Infrastructure Organisation to carry out archaeological investigations ahead of development for the Army Basing Programme. These works collectively involved an ambitious project to accommodate the 4000 additional Service personnel and their families based on and around Salisbury Plain from 2019. Excavations took place in and around the existing military bases at Larkhill, Bulford, Tidworth and Perham Down, with ancillary works at Ludgershall and between Bulford and Tidworth (Figure 1).

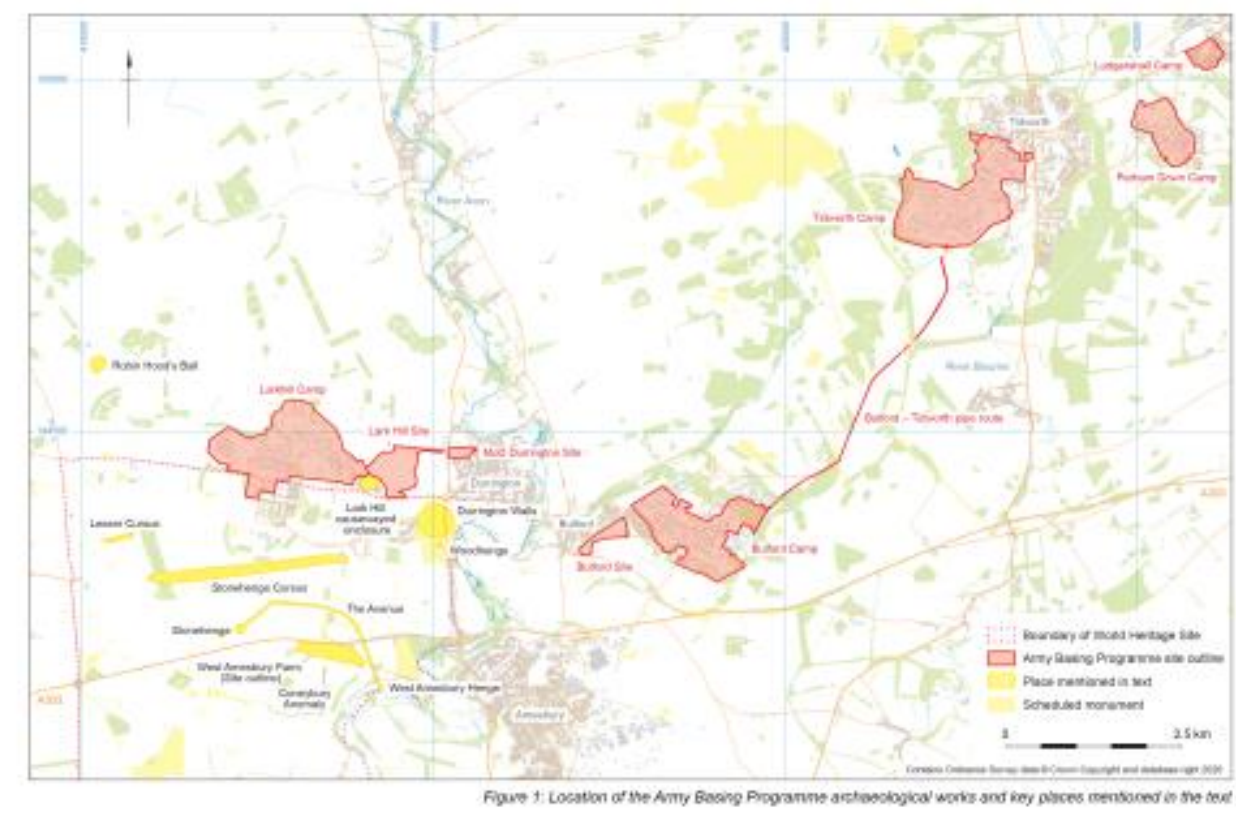

Figure 1: Location of the Army Basing Programme archaeological works and key places mentioned in the text

As a whole, the Programme revealed evidence of the human use of the area from the Early Neolithic to the Second World War, with important evidence of the development of 
infantry warfare during World War 1 being a particularly significant result from Larkhill (Brown and Thompson 2018). Preliminary results and summaries are available (Leivers 2017a; 2017b; Brown and Thompson 2018), while an Early Bronze Age possible log burial has been published in full (Powell and Legg 2020). This article discusses the major discoveries dating to the Neolithic and Early Bronze Age from these excavations, and attempts to set them in the wider context of the landscape preceding Stonehenge, of Stonehenge itself, and of the development of the ceremonial landscape into the Early Bronze Age. Full publication of the Programme's results will follow an extensive programme of post-excavation analysis.

\section{Before Stonehenge - the Early Neolithic (38th to 33rd centuries BC)}

Lark Hill is a low eminence that currently forms part of the northern boundary of the Stonehenge World Heritage Site. The Stonehenge Riverside Project identified the southeastern end of the hill over a decade ago as a key point in the Stonehenge landscape: the spot commands 'dramatic viewsheds of round barrow cemeteries as well as the major monuments, including a midwinter sunset solstice vista along the Avenue and into Stonehenge' (Parker Pearson et al. 2004, 54; 2020, 26). This understandable focus on Stonehenge is perhaps what diverted attention away from Lark Hill's north-eastern slopes (from which Stonehenge is not visible), where some remarkable Early Neolithic evidence is situated, including a newly discovered causewayed enclosure (Figure 2).

\subsection{The Lark Hill causewayed enclosure}

A $125 \mathrm{~m}$ long gently curving arc of five segments of ditch lay within the limit of excavation, with the rest of the circuit and almost the entire interior uninvestigated within the Ministry of Defence's Larkhill Camp. This means that the enclosure's size and morphology is mostly unknown: the possibility of multiple ditch circuits remains untested, as does the existence of any internal features. All that can be said for certain is that the segments of ditch within the excavations are the outer circuit on the north-east side (no further circuits were found within the extensive excavated areas outside the enclosure), and that, assuming a reasonably circular shape, the enclosure sat on the north-western summit of Lark Hill and partly on its northern slope (Figure 2). This location places it above the head of a dry valley that may have been seasonally wet and which leads down to a large meander in the Avon. 


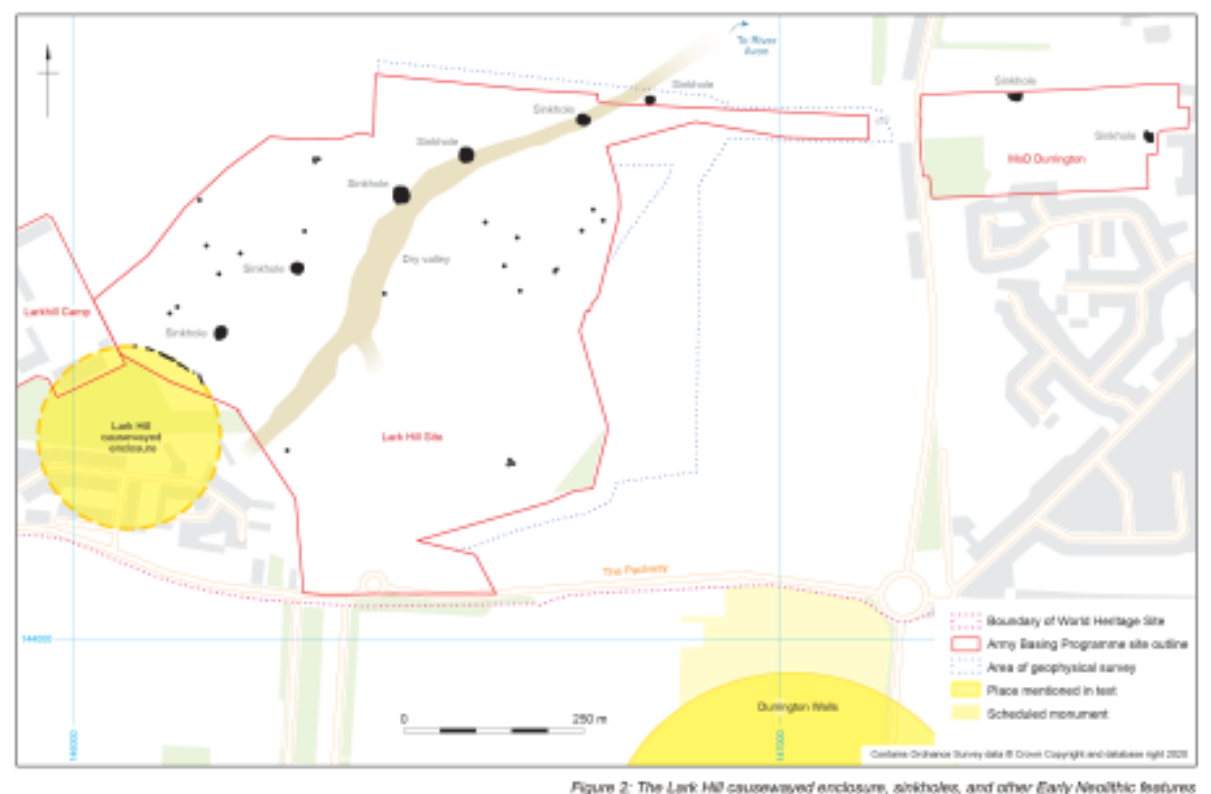

Figure 2: The Lark Hill causewayed enclosure, sinkholes, and other Early Neolithic features

A cattle tibia from a Hembury Ware-containing fill low in the sequence (but not on the ditch bottom) provides a date for the enclosure. This bone produced an unmodelled radiocarbon date of 3780-3650 cal BC (SUERC-70507: 4937 $\pm 31 \mathrm{BP}$ ), providing a terminus post quem for the original fills of the ditch. This date makes the enclosure one of the two earliest dated Neolithic structures currently known in the Stonehenge environs, along with the Coneybury 'Anomaly' which has modelled dates between 3800 $3700 \mathrm{cal} B C$ (95\% probability) or more likely between $3760-3700 \mathrm{cal}$ BC (68\% probability) (Barclay et al. 2018).

\section{The causewayed enclosure's relationship to the wider landscape}

There are other suggestions of a date at the very beginning of the period for the Lark Hill enclosure. 


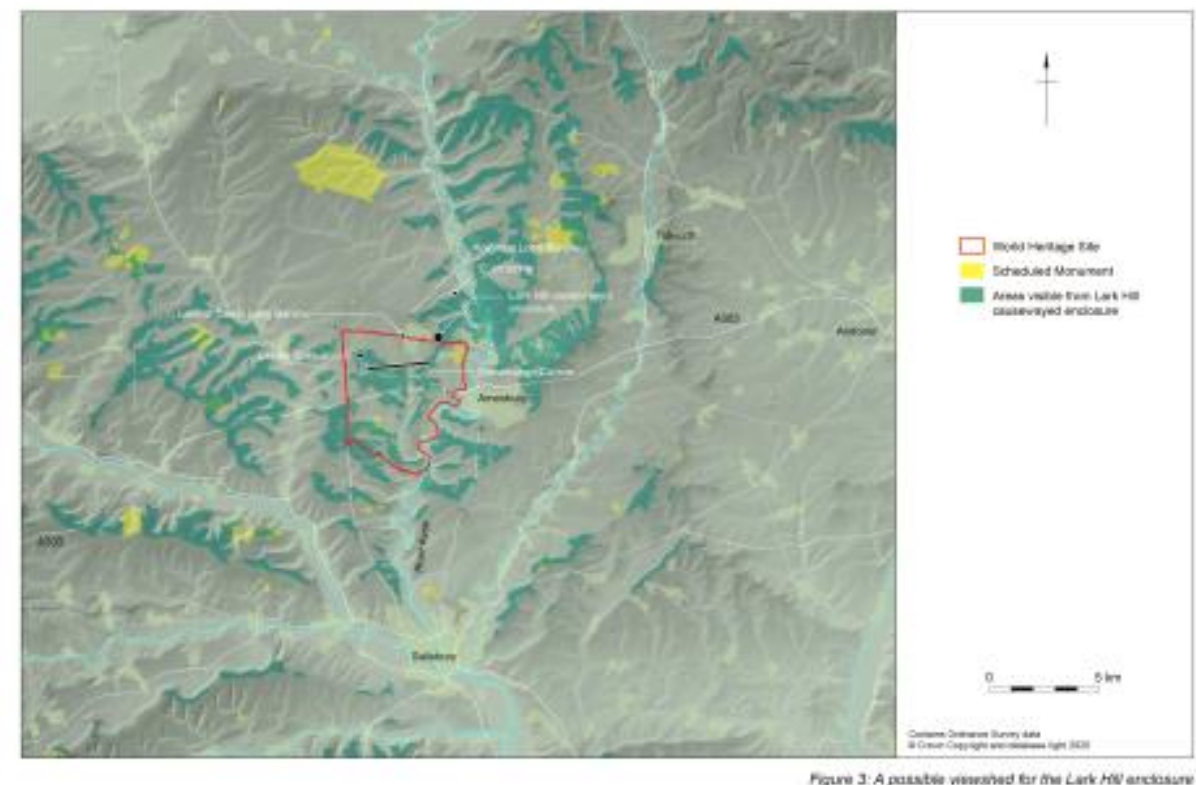

Figure 3: A possible viewshed for the Lark Hill enclosure

The viewshed seen in Figure 3 was constructed using a grid of observer points with the eye level at $1.6 \mathrm{~m}$ above the surface over an approximately circular structure of comparable size to the enclosure at Robin Hood's Ball, around an estimated centre point at NGR 414091 144275, using a bare earth elevation model.

Figure 3 shows the undated Knighton (FIG27) and Larkhill Camp (DUR24) long barrows on islands of visibility in locations that are unlikely to be coincidental, implying that the causewayed enclosure already existed at the time of their construction. It may be significant in view of the argument advanced below that the locations of both ends of the Stonehenge Cursus as well as the entire length of the Lesser Cursus (both later structures) are likely to have been visible.

Longer-distance instances of intervisibility are also apparent. The military track from Knighton Farm and ' $\mathrm{C}$ ' Crossing to Allanbrooke Barracks and Knighton long barrow follows the ridgeline forming the northern slope of the dry valley at the head of which the Lark Hill enclosure sits. The enclosure is on the near horizon to the south, the northern horizon marked by the edge of the Marlborough Downs. Both Adam's Grave and the causewayed enclosure on Knap Hill are clearly visible from this point at a distance of almost $20 \mathrm{~km}$. Evaluation on the ' $\mathrm{C}$ ' Crossing ridge has found at least one pit containing Early Neolithic flint work (Wessex Archaeology 2001). 


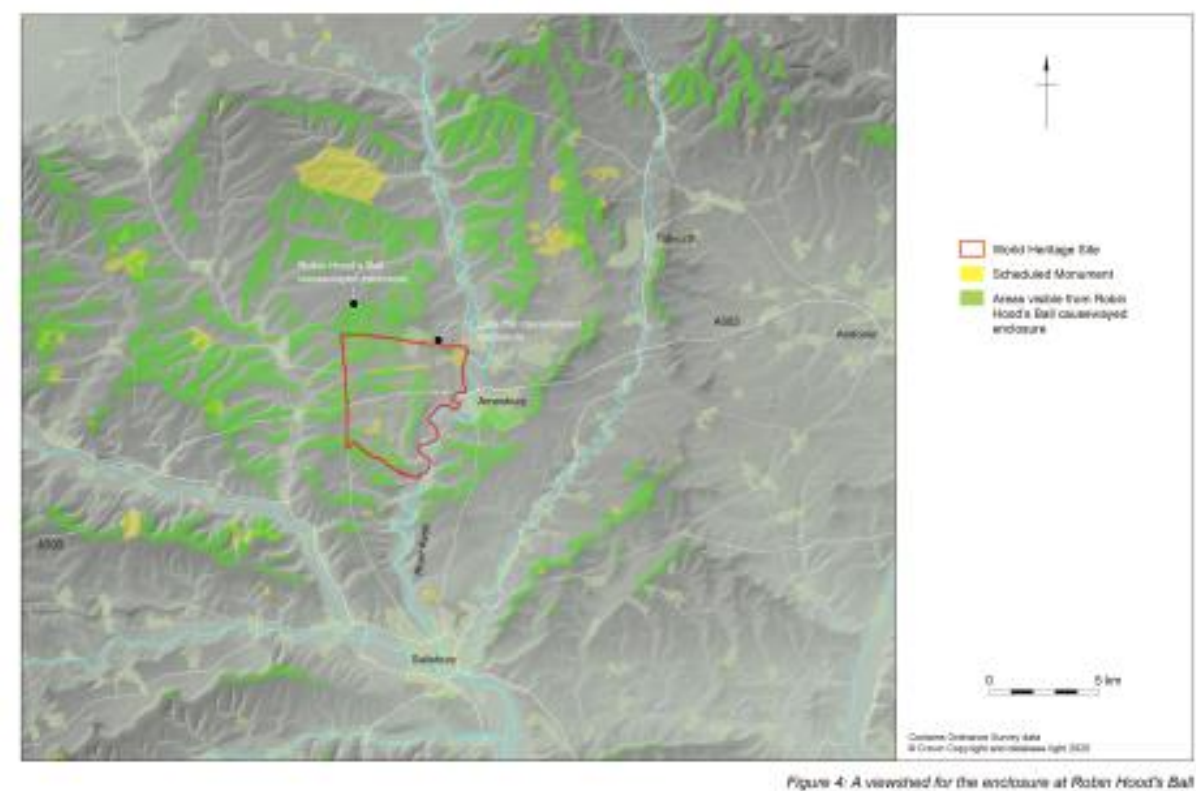

Figure 4: A viewshed for the enclosure at Robin Hood's Ball

A comparison of the viewsheds of the region's two causewayed enclosures is instructive. Viewsheds for the Robin Hood's Ball enclosure have been published in Batchelor 1997, plan 7 and Exon et al. 2000, 33, fig. 4.3; a new version from a grid of observer points across the Robin Hood's Ball enclosure is in Figure 4. An overlay of the viewsheds for Robin Hood's Ball and Lark Hill is in Figure 5 (a larger scale detailed zoomable viewshed for the Lark Hill enclosure is also included - Figure 5a). Neither enclosure is visible from the other, Robin Hood's Ball in particular sitting in a large island of invisibility as viewed from Lark Hill.

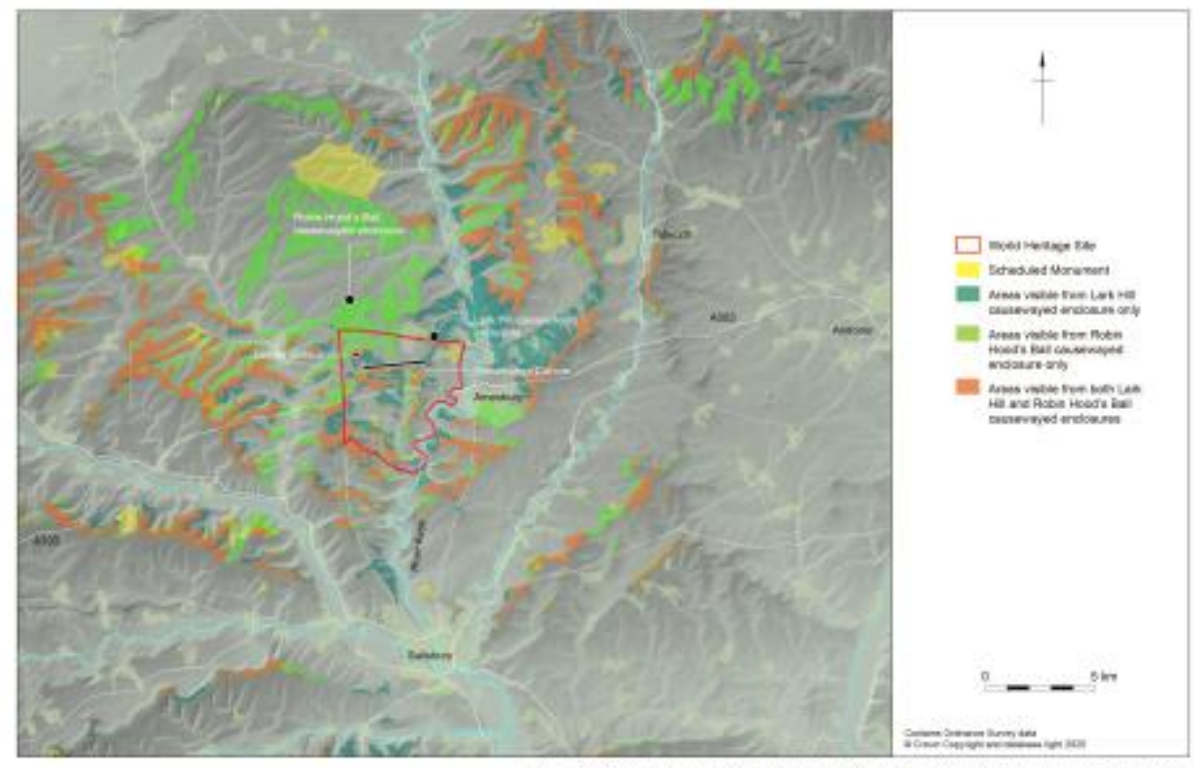

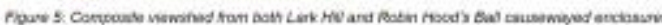


Figure 5: Composite viewshed from both Lark Hill and Robin Hood's Ball causewayed enclosures

Several relationships are of note, such as the Lesser Cursus being visible from both causewayed enclosures, while the ends of the Stonehenge Cursus are invisible from the Robin Hood's Ball enclosure, with only portions of the interior and the ridge later occupied by the Cursus Barrows visible from there.

\section{[ZOOMABLE FEATURE AVAILABLE ONLINE ONLY]}

Figure 5a: A detailed viewshed for the Lark Hill enclosure. The Knighton and Larkhill Camp long barrows sit on the margins of islands of visibility; both ends of the Stonehenge Cursus are within view. The enclosure at Robin Hood's Ball and its barrows are not. [Download large image]

Particularly interesting are the sites of the Larkhill Camp (DUR24) and Knighton (FIG27) long barrows (Figure 6). As noted, both long barrows sit on islands of visibility from Lark Hill but, remarkably, both are at the very limits of visibility from Robin Hoods Ball also, on the far horizon for each causewayed enclosure. Indeed, the viewsheds suggest that that, for both barrows, one side was visible from one enclosure and the other side visible from the other, with the top of both barrows visible from both: they seem to lie literally on the join between the viewsheds.

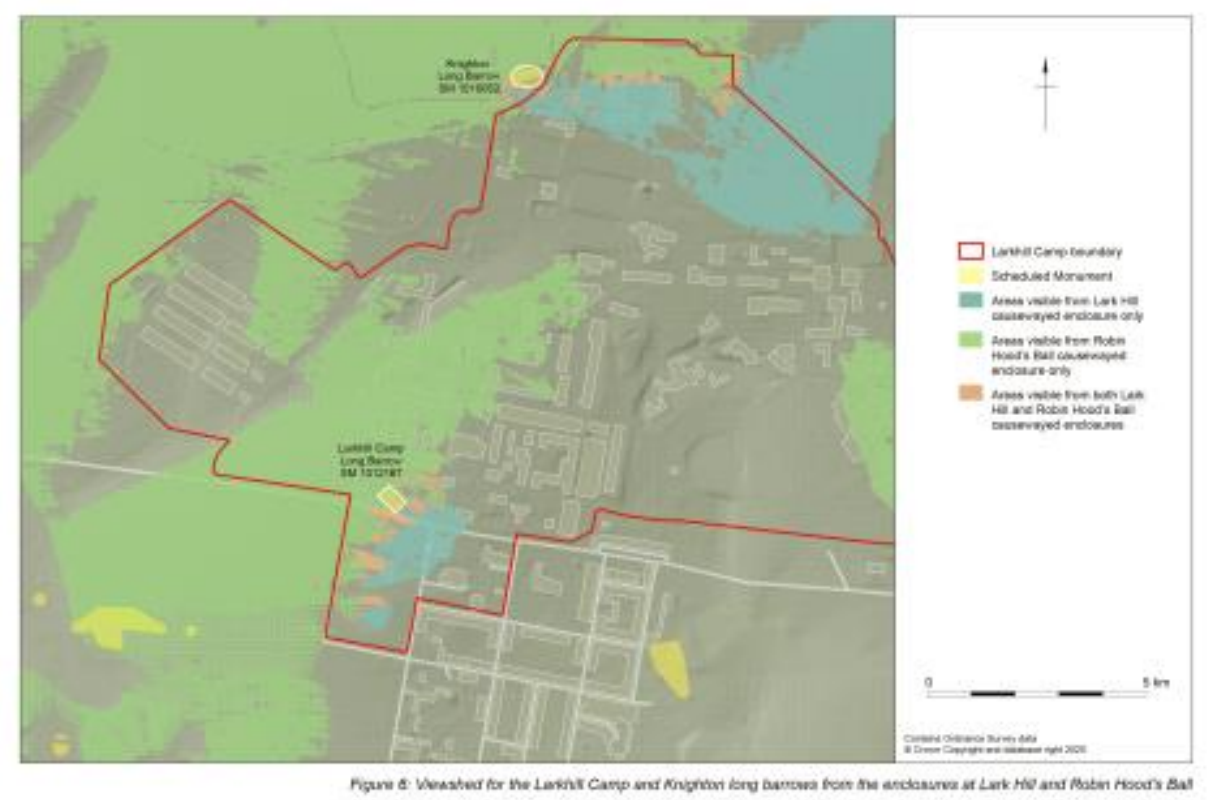

Figure 6: Viewshed for the Larkhill Camp and Knighton long barrows from the enclosures at Lark Hill and Robin Hood's Ball

\subsection{The setting of the causewayed enclosure}

The arrangement of the excavated ditch segments suggests an entrance through the ditch (and presumably the vanished bank). An unusually wide causeway occupied 
centrally by a large shallow pit separates the south-easternmost pair of excavated ditch segments. The terminal of the south-easternmost ditch at the entrance flares outward from the interior, an arrangement echoed much later at Durrington Walls where 'a curious arrangement of ditches [at the entrance], with the righthand ditch terminal (when exiting the monument) slightly curved outwards' was noted (Parker Pearson et al. 2004, 48). The whole arrangement suggests an entrance overlooking the dry valley, giving the enclosure as a whole a north-eastward aspect.

Five large features of differing sizes and spacing but between 18 and $24 \mathrm{~m}$ in diameter were located along the south-east-facing slope of the dry valley (Figure 2). Excavation demonstrated some of these to be solution hollows, part of a broader system of similar features, while geophysical survey detected a sixth comparable anomaly continuing the line to the east (Schmidt and Crabb 2017). Wessex Archaeology had previously investigated two further solution hollows approximately $600 \mathrm{~m}$ further to the east at the former MoD Headquarters in Durrington (Thompson and Powell 2018)).

These natural hollows have recently been reinterpreted as part of a massive pit structure surrounding Durrington Walls (Gaffney et al. 2020), and while the pattern of features is plausible, the examples encountered at Lark Hill and MoD Durrington that were tested by excavation were undoubtedly geological in origin. While this need not be an obstacle to the existence of the 'massive pit structure', it does suggest a rather different form, meaning and chronology to that suggested by Gaffney et al. (2020).

Given that at least some of the five large hollows encountered at Lark Hill are geological, they would have been visible in the landscape at the beginning of the Early Neolithic. That they were, and that they were significant in the siting of the causewayed enclosure, is demonstrated by the fact that the large shallow pit in the enclosure's entrance lies on their line, and may have been an attempt to incorporate them into the enclosure's architecture. The pit in the enclosure's entrance contained Early Neolithic pottery and struck flint; the excavated parts of the solution hollows did not contain contemporary material, although engineering constraints limited investigation of the examples within the footprint of the Army Basing Programme developments to a maximum depth of $2 \mathrm{~m}$.

Two points are of significance. First, the situation of the Lark Hill enclosure at the head of a dry valley leading to the first of the large meanders in the Avon is mimicked in the Late Neolithic by the siting of Durrington Walls. This very large henge was constructed around the head of a short dry valley that continues beyond the enclosure's southeastern entrance to another large meander in the Avon. To a lesser extent the arrangement is later echoed by the Stonehenge Avenue, which leads north-east from Stonehenge on the midsummer sunrise alignment, before turning sharply just south of eastwards and then south-eastwards to the third meander of the river downstream of Larkhill.

The alignment of the Stonehenge Avenue on (and the aspect of the entrance of the earliest phase of Stonehenge towards) the midsummer sunrise highlights the other point of significance of the Lark Hill causewayed enclosure's location. Its aspect northeastward out of the entrance along the line of solution hollows is directly toward the western shoulder of Sidbury Hill, which marks the highest point on the northern horizon, from behind which the sun rises on the midsummer solstice (Figure 7). This alignment is marked in a much more formal way at the end of the Neolithic period, discussed below. 


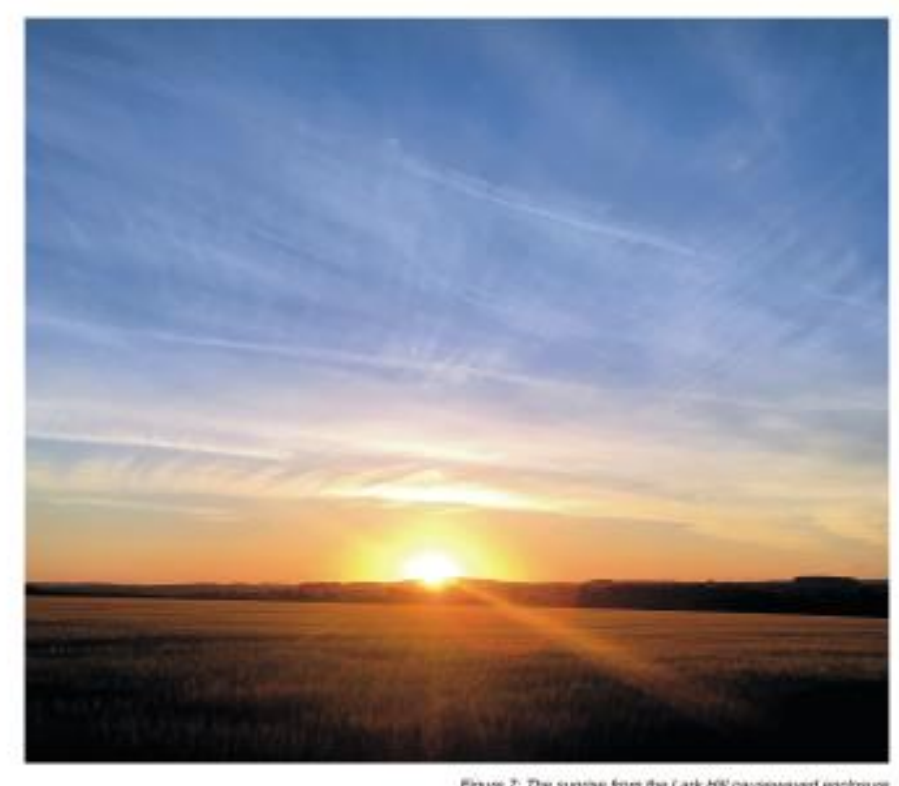

Figure 7: The sunrise from the Lark Hill causewayed enclosure

This is the single most important discovery from the Army Basing Programme: the incorporation of natural features marking this solstice alignment into the built architecture of the landscape perhaps 700 years before the building of the first phase of Stonehenge.

\subsection{Other Early Neolithic evidence on Lark Hill}

Other Early Neolithic features on Lark Hill include 26 mostly dispersed pits distributed unevenly across the site (Figure 2). There is no apparent pattern, and whatever the solution hollows may have come to represent later in the Neolithic in terms of a boundary marker or separator of spaces, they had no such significance in the Early Neolithic, if such can be determined from the distribution and contents of the mostly small pits on either side of them.

Only one pit in the south-eastern part of the site was notable, for both its size and contents. Much larger (over $2.4 \mathrm{~m}$ in diameter) than the other examples (most no more than $1 \mathrm{~m}$ in diameter), it contained the fragmented remains of a 14-30 year-old, possibly female. Other human remains were recovered from Early Neolithic contexts (including the causewayed enclosure ditches), but in much smaller quantities.

\subsection{Early Neolithic evidence at Bulford}

Another Early Neolithic inhumation was found at Bulford, a second Army Basing Programme site $3.5 \mathrm{~km}$ to the east-south-east of Larkhill (Figure 8). 


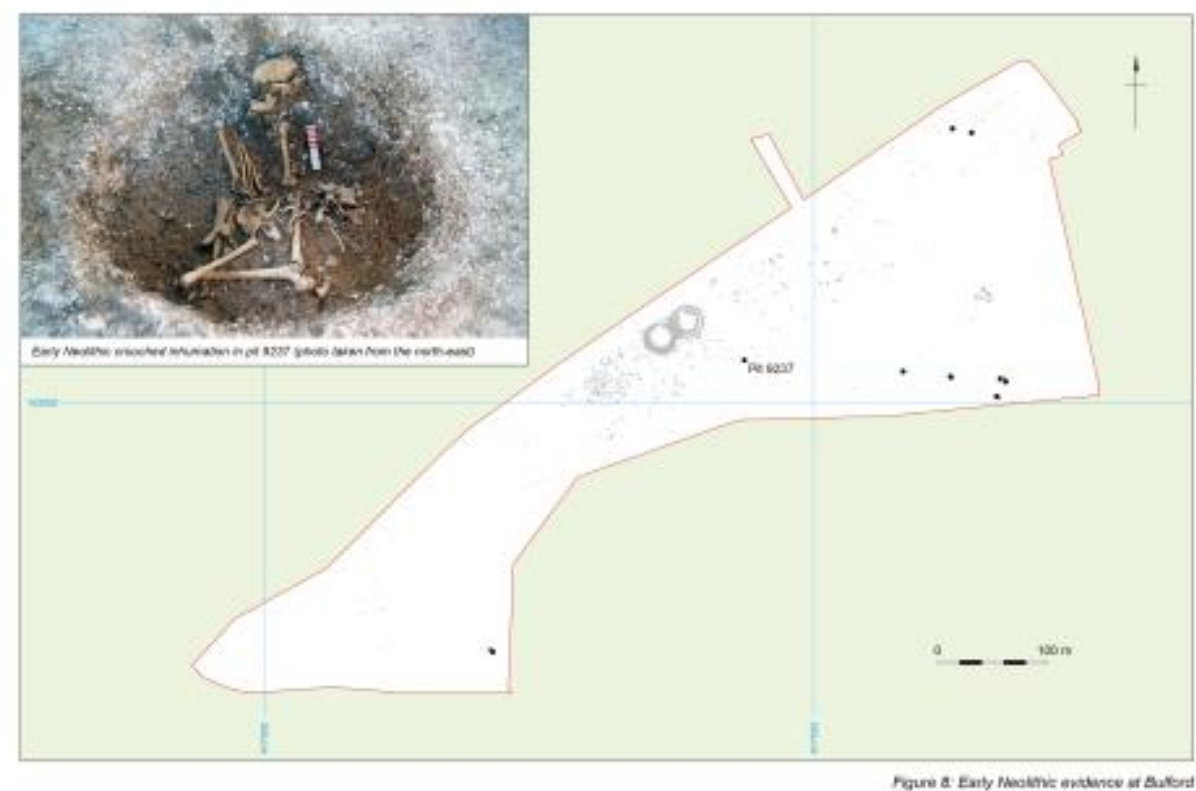

Figure 8: Early Neolithic evidence at Bulford

Here, a single inhumation burial was that of a young adult, possibly male, placed on a mound of chalk in a pit and covered with a deposit of animal bones. Deliberate manipulation was visible among features of the burial, including the rectilinear arrangement of the long bones of the lower limbs and many of the bones of the axial skeleton and the smaller bones of the hands and feet to the right of the in situ remains in an apparently random scatter. A sample of the right femur returned a modelled date of 3530-3360 cal BC (86.0\%) at 95\% probability (SUERC-80712: 4671 25 BP, 3520$3370 \mathrm{cal} \mathrm{BC})$.

The burial sat on the crest of a ridge at the top of a coombe that contained evidence of occupation: a spread of flint-knapping waste (some definitively Early Neolithic) and five pits in two groups containing hazelnut shells, which produced a modelled radiocarbon date of 3390-3180 cal. BC (59.1\%) at 95\% probability (UBA-36393: 4590 \pm 32 BP, 3500$3120 \mathrm{cal}$. BC). Associated artefacts consisted of flaking debris including microdebitage and retouched tools, Early Neolithic pottery, bone and sarsen fragments. It is possible to interpret the distribution of the groups of pits as marking the location of a structure in the base of the coombe, arranged around a 'house void' (Garrow et al. 2006; Chaffey and Brook 2012). Three more Early Neolithic pits sat on the spur immediately to the west of the coombe, below the burial; two more lay on the high ground to the north-east while a further two lay on the high point to the south-west. All contained Early Neolithic ceramics and struck flint.

\section{The Early Neolithic landscape}

How do the causewayed enclosure on Lark Hill and the burial on the hilltop at Bulford fit into the wider pattern of Early Neolithic ceremonial architecture in the area?

The Stonehenge Cursus runs for $2.8 \mathrm{~km}$ in a broadly west-south-west to east-northeasterly direction, although it is not straight: both ends narrow giving the western end a 
pronounced westward turn and the eastern end a less pronounced trend to the east where it terminates a little way short of the Amesbury 42 long barrow, which lies transversely to the line of the Cursus. Excavations of the Cursus in 2007 by members of the Stonehenge Riverside Project (Parker Pearson et al. 2007a) recovered antler from the base of the western terminus that gave radiocarbon determinations of 3630-3375

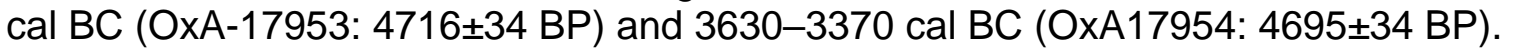
These dates are definitively Early Neolithic (Thomas et al. 2009) and place the construction of the Cursus centuries before the first phase of Stonehenge (the ditch dating to 2990-2755 cal BC: Marshall et al. 2012).

That the Cursus clearly pre-dates Stonehenge is critical, since the relationship between the two is central to understanding the location and purposes of both, as well as the location of other important places locally. Viewed from the Stonehenge circle, the eastern end of the longest, effectively straight (central) portion of the Cursus is broadly on the alignment of the midsummer sunrise. Similarly, the western end of the long portion (although invisible from within Stonehenge, hidden as it is by the near horizon on which the later Cursus Barrows sit) is broadly on the alignment of the midsummer sunset. This latter alignment is later shared by the Durrington Walls 'Avenue' as it climbs from the Avon meander towards the later henge's south-eastern entrance and the Southern Circle (Parker Pearson 2012, 79-81). The Stonehenge Hidden Landscape Project identified large geophysical anomalies, perhaps pits, within the Cursus at the points where these solstice alignments from Stonehenge intersect with its line (Gaffney et al. 2012). Given the midsummer solstice aspect of the Lark Hill enclosure's entrance a century or more previously it seems unlikely that the general and - assuming the geophysical anomalies within the Cursus are contemporary archaeological features specific solstice referents of the Cursus are coincidental. Similar relationships exist; the setting of the midwinter sun between the banks of the Dorset Cursus behind the long barrow on Gussage Cow Down (Barrett et al. 1991, 50, fig. 2.16), for instance. For this to hold at Stonehenge of course requires that there was something at Stonehenge half a century prior to its earliest phase as currently understood.

Perhaps there was. Pitts has suggested that the Stonehenge ditch may have incorporated earlier features (Pitts 2012). Some combination of features hinted at by the 'North Barrow' and the low mound identified by Bowden et al. $(\underline{2015}, 28-32)$ may have marked the spot. Perhaps it was the Altar Stone, shaped at one end and probably once a standing stone. The centre of the circle has been very much disturbed over the centuries: the Duke of Buckingham caused it 'to be digged' in the 17th century (Walker 1995, 9); a century later, William Stukeley had a hole dug against the Altar Stone (Burl 2006, 45). William Cunnington excavated in front of the Altar Stone at the start of the 19th century (possibly destroying a prehistoric feature in the process: Parker Pearson 2012, 32), while Captain Beamish returned to the spot around 1839 (Walker 1995,9$)$. Traces of a post or other marker having stood in this location are unlikely to have survived these early attentions. Parker Pearson et al. (2007b, 623-6) have suggested that a large pit dug in $2450-2210$ cal. BC may have removed a large (perhaps natural) stone from the circle's centre.

What of the Cursus itself? Its line is not straight. As Thomas et al. noted, the first $600 \mathrm{~m}$ of the southern ditch at the western end align on Beacon Hill. Further to the east the line is toward the Amesbury 42 barrow on King Barrow Ridge (Thomas et al. 2009, 51), although the apparent contemporaneity of the two means that it is unlikely that Amesbury 42 was the cursus's target. The dominant line of the Cursus continues beyond its eastern terminal through the Cuckoo Stone and Woodhenge, both associated with 
Early Neolithic activity in the form of pits or tree hollows containing cultural material (Thomas et al. 2009, 42; Parker Pearson et al. 2020, 136ff). The line then cuts across the meander in the Avon later connected to Durrington Walls, to climb the flat hilltop at Bulford occupied by the manipulated Early Neolithic inhumation burial described above (Figure 9). Westward, the line intersects with the long barrow on Winterbourne Stoke Down (WIN53) (Exon et al. 2000).

It is clear, then, that the line occupied in part by the Stonehenge Cursus was of some significance, both in the Early Neolithic and later. Why, then, was some part of it given physical expression by the banks and ditches of the Cursus itself, while other parts were referenced by the siting of other features? It can only be that the Cursus marks the part of this line between midsummer sunset at the western end, and midsummer sunrise at the eastern. In effect, the Cursus marks the part of the sky in which the sun never appears and, perhaps more speculatively, its path beneath the ground on the shortest nights of the year when viewed from what became Stonehenge.

Here then is proof-positive that the Cursus is a path, but not necessarily (or not only) one trodden by human feet. It marks the descent of the sun below ground, its passage under the earth, and its eventual re-emergence into the world. Here is our first pointer towards the answer to Richard Atkinson's 'we do not know' questions: the questions about Stonehenge beginning with 'why?' (Atkinson $\underline{1979}, 178)$.

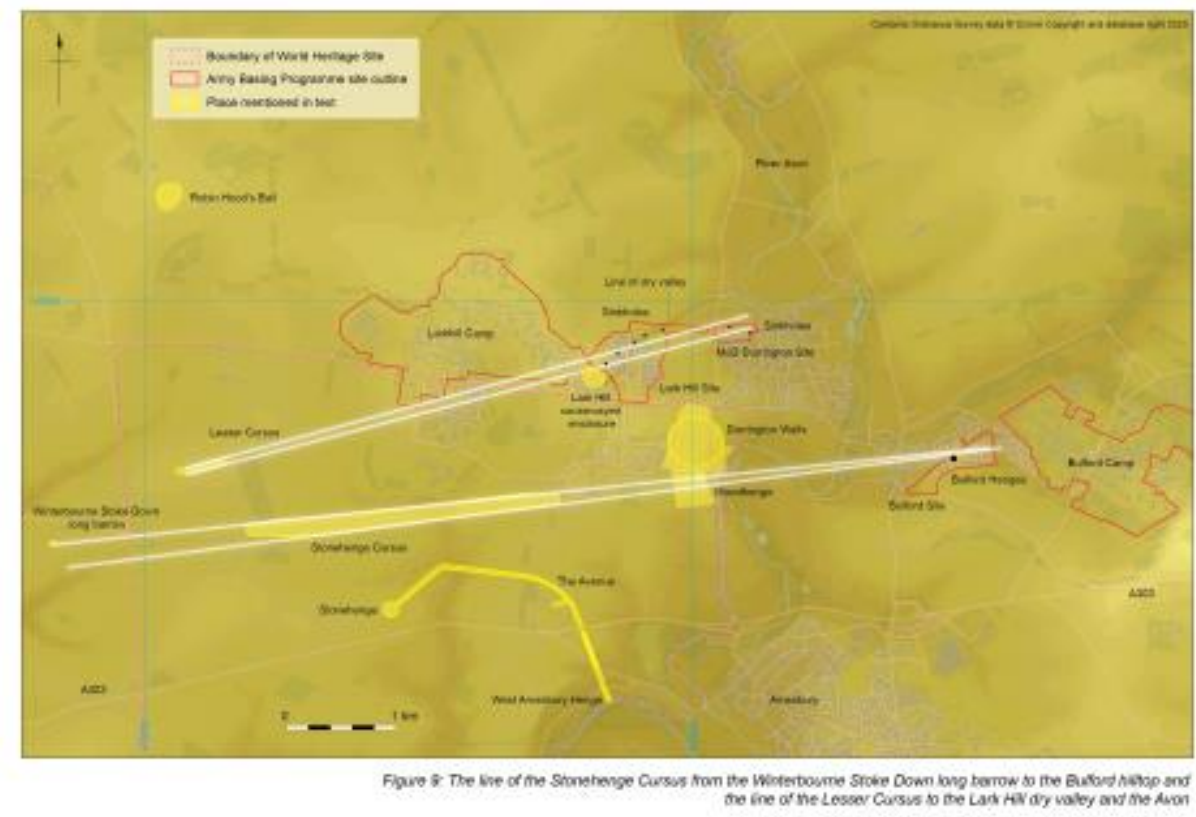

Figure 9: The line of the Stonehenge Cursus from the Winterbourne Stoke Down long barrow to the Bulford hilltop and the line of the Lesser Cursus to the Lark Hill dry valley and the Avon

A less convincing case for cosmological integration can be made for the Lesser Cursus, dated on the basis of antler picks in the phase 1 and phase 2 ditches to 3496-3042 cal

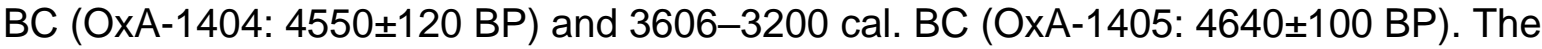
location of this structure takes advantage of 'the summit of a remarkably flat ridge top' (Richards $\underline{1990}, 72$ ), and the coincidence of its extrapolated line in its east-north-easterly 
direction is revealing. Some $3.8 \mathrm{~km}$ from the cursus's western terminus, the line reaches the dry valley leading to the meander in the Avon, above which sits the causewayed enclosure on Lark Hill (Figure 9). Exon et al. suggested that the Lesser Cursus may have been constructed with reference to the line between the long barrow on Winterbourne Stoke Down (their number 14, which sits on the path of the Stonehenge Cursus) and Knighton Down (their number 29), 1.6km west of the Lark Hill enclosure $(\underline{2000}, 44)$. The trend is general rather than specific, and the dry valley down from Lark Hill to the Avon is a more exact match (there is no way the authors of that study could have recognised the significance of the spot, of course, as the causewayed enclosure was invisible to every non-invasive technique).

What does not fit into this pattern are the region's other causewayed enclosure at Robin Hood's Ball, the pits and artefact scatter outside it and elsewhere in the area, and the various long barrows. Of the latter, Exon et al. noted the way various groups are arranged around the heads of dry valleys $(\underline{2000}, 39)$ while David Field noted a similar phenomenon among groups of barrows on the Salisbury Plain Training Area (McOmish et al. 2002, 23-7). Additions and subtractions from the long barrow corpus only seem to strengthen the association (Roberts et al. 2018). The causewayed enclosure at Robin Hood's Ball stands out as the lone example of a major Early Neolithic earthwork not tied to the system of (perhaps seasonally wet) dry valleys, and it contrasts with Lark Hill in other ways. Lark Hill commands views along the valleys of the Avon and Wylye to the north, south and west, but has no view of much of the downland between the Lesser Cursus and Robin Hood's Ball. The latter site has a viewshed dominated by areas to its south and west, as well as south of Amesbury and Bulford Camp on the eastern horizon (Exon et al. 2000, 32-4).

\section{The First Stonehenge - the Start of the Late Neolithic (30th Century BC)}

Some centuries after the burial of the lone young adult male at Bulford, people returned to the hilltop. Ceramics (Woodlands Grooved Ware) place this activity firmly in the Late Neolithic, but the associated radiocarbon dates are early - at the very beginning of the third millennium, coincident with the construction of the circular ditch and banks of Phase 1 of Stonehenge.

\subsection{The Bulford pits}

At Bulford, 48 pits formed a scatter around the crest of the hilltop (Figure 10), in a band extending eastwards from the highest part of the hill to where the densest concentration of features followed the $95-96 \mathrm{~m}$ contours around the slope to the north. This distribution strongly favoured the viewshed to the east, up the Nine Mile River valley towards Sidbury Hill. 


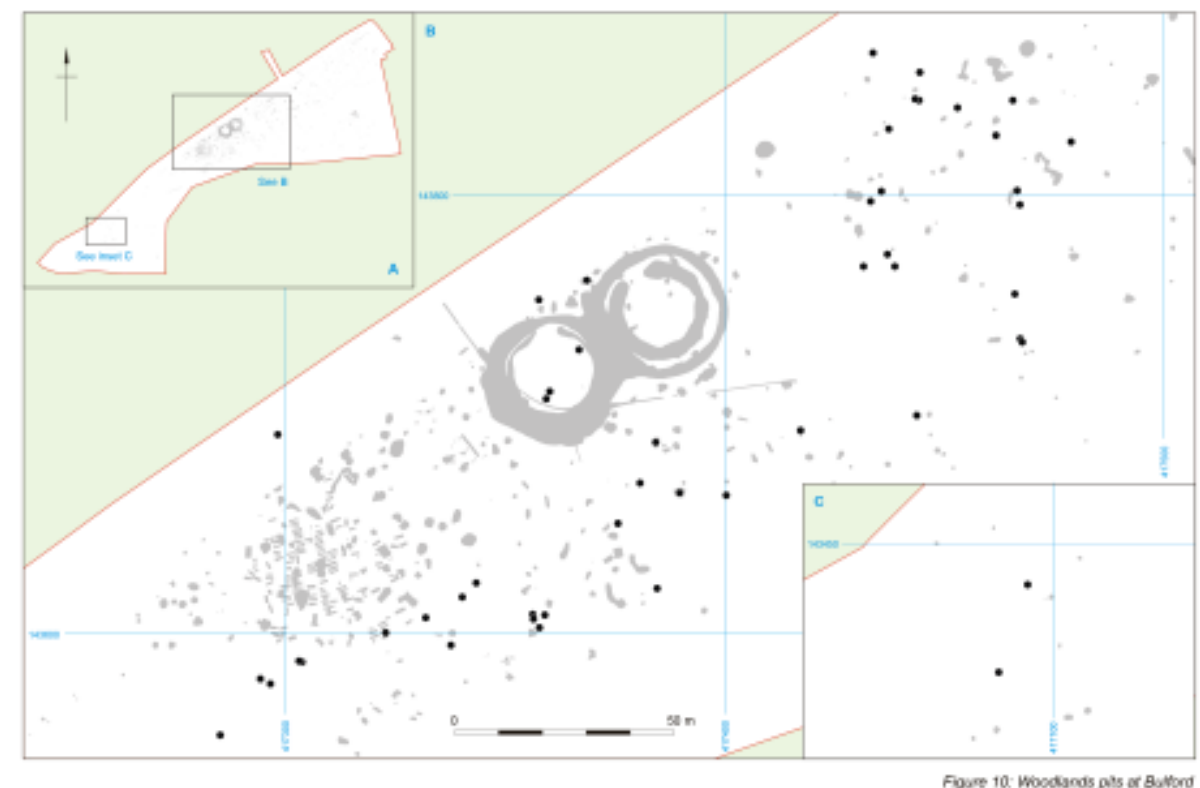

Figure 10: Woodlands pits at Bulford

The pits contained animal bone, pottery, flint-knapping debris, retouched tools and charcoal in varying quantities, dog coprolites and a number of flint spheres (generally unused but found in larger numbers than might be expected). A range of other objects including carved chalk, flint and stone axes or fragments, a discoidal knife, antlers and aurochs bones, the talons of a sea eagle, and beads were also present. The assemblages suggest a range of domestic, ceremonial and feasting activities. In some instances the quantity and range of special objects seems disproportionately large compared to those of more conventional artefact types, and some of the pits (or pairs of pits) incorporated elements of structured deposition.

Thirty-eight of these pits contained over 1300 sherds of Woodlands Grooved Ware. Radiocarbon dates obtained from animal bone and charred hazelnut shells in the same features have provided modelled dates centred on $2950 \mathrm{cal} \mathrm{BC}$, indicating that the Woodlands Grooved Ware from Bulford is almost as early (if not as early) as that from Orcadian sites claimed to be the style's place of origin. Modelling of Orcadian radiocarbon determinations has suggested that the Grooved Ware assemblage from Barnhouse dates to between 3160 and $3090 \mathrm{cal} \mathrm{BC}$ and 2890-2845 cal BC; that from Sanday to between $3210-2935 \mathrm{cal} \mathrm{BC}$ and $2815-2650 \mathrm{cal} \mathrm{BC}$; and the Stones of Stenness the sequence starts at 3020-2890 cal BC (Richards et al. 2016).

Such apparent contemporaneity poses several questions about contact between Wessex and Orkney around $3000 \mathrm{BC}$, but it is significant in a second way, as being exactly contemporary with the construction of Phase 1 of Stonehenge. The phase 1 Stonehenge ditch is dated to 2990-2755 cal BC (Marshall et al. 2012), while Aubrey Hole 32 dates to 3000-2890 cal. BC (Parker Pearson et al. 2008, 18). It seems inconceivable that the community undertaking whatever activities resulted in the Bulford pits did not know about Stonehenge, and it is at least possible, and even probable, that the builders of Stonehenge and the Bulford people were the same. If this is the case, and if the Aubrey Holes were the earliest phase of Stonehenge, and if it is true that they 
mark the location of a bluestone circle (Parker Pearson et al. 2020, 164-8), what made users of 'Orcadian' pottery bring stones from Wales to this spot in southern England? The spot on which Stonehenge was built was already special, and its renown (made so evident later in its life by stable isotope analysis) may have been widespread, even at the start of the third millennium.

\section{In the Lifetime of the Stones - the End of the Late Neolithic and Beakers (27th to 21st Centuries BC) 4.1 The Bulford henges}

There are no dates for the erection of the Bulford Tor Stone, $0.4 \mathrm{~km}$ south of the hilltop. The existence of modified natural sarsen boulders variously adjacent to the later henges at Stonehenge, Woodhenge and Bulford - the Tor Stone and Cuckoo Stone are approximately the same distance from their henges; the Heel Stone very much closer is unlikely to be coincidental.

On the hilltop at Bulford, by this time a location of great traditional significance over perhaps a millennium, two small henges were situated immediately adjacent to each other, both approximately $20 \mathrm{~m}$ in external diameter and each with a single entrance on the northern side, constructed as a series of conjoined gang-dug segments, separated by low causeways (Figure 11). No internal features survived in either and although evidence is not conclusive, the ditch fills suggest that the western henge had an internal bank, while the eastern could have had a bank outside its ditch.

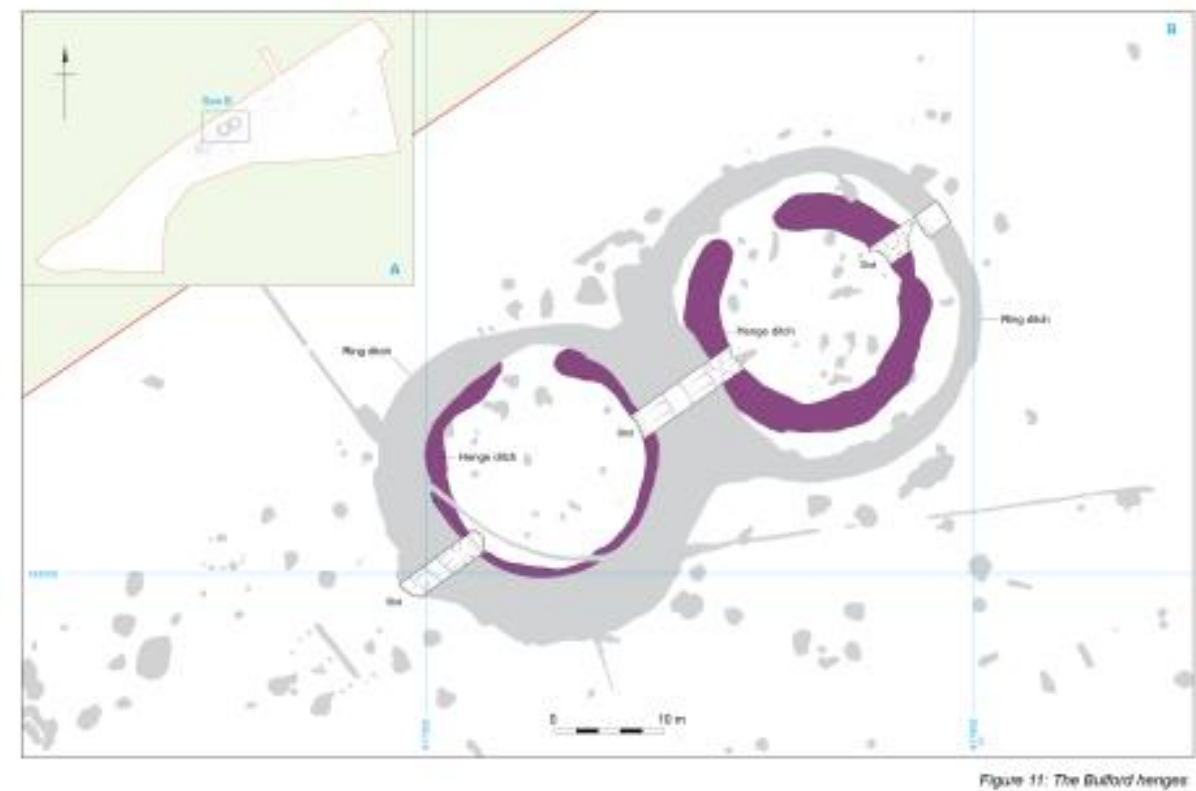

Figure 11: The Bulford henges 
Excavation was limited since both have been preserved and scheduled and excavation was only undertaken to inform the scheduling process. Artefacts were consequently scarce, but the eastern henge is dated by a pig humerus from secondary silts modelled as 3100-2920 cal BC (SUERC-78117: 4394 \pm 29 BP, 3090-2920 cal BC) and hazelnut shell modelled as 2910-2630 cal BC (UBA-36926: 4208 \pm 46 BP, 2910-2640 cal BC). Primary deposits in other ditch segments, however, contained sherds of undecorated Grooved Ware and charcoal that returned a date modelled as $2880-2580$ cal BC (UBA36925: 4130 $\pm 32 \mathrm{BP}, 2870-2580 \mathrm{cal} \mathrm{BC})$. That these potentially early dates are not entirely erroneous is suggested by other finds from the ditches including a chisel arrowhead, although a dog skull from the same layer at the base of the secondary fills

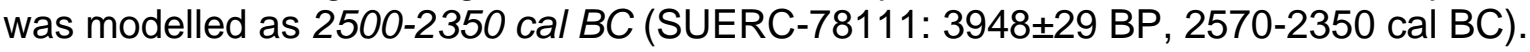

The western henge included fragments of undecorated Grooved Ware pottery on the base of the ditch on the western side. Food residue from the surface of the sherd produced a radiocarbon date modelled as 2570-2460 cal BC (SUERC-78118: 3989 \pm 29 $\mathrm{BP}, 2570-2470 \mathrm{cal} \mathrm{BC})$. A sample taken from a pig tibia found at the base of the ditch on the eastern side was modelled as 2560-2460 cal BC (SUERC 78116: 4005 229 BP, 2580-2470 cal BC), making the construction of the western henge (if not both) contemporary with the erection of the Stonehenge sarsen circles and the lifetime of the Durrington Walls 'village'.

Similar small henges exist elsewhere around Stonehenge. The (perhaps somewhat later) West Amesbury henge on the banks of the Avon at the end of the Stonehenge Avenue is approximately $20 \mathrm{~m}$ in diameter (Parker Pearson 2012), while the 'pit circle' beneath Amesbury 6 (240m west-south-west of Stonehenge) appears to be very similar in terms of size, configuration, and later alteration (Field et al. 2014, 13, fig. 10).

\subsection{Other Late Neolithic activity at Bulford}

Contemporary activity on the hilltop includes a group of six pits above the coombe, east of the henges. Two fragments of a snapped but conjoining red deer tine, which produced a radiocarbon date modelled as 2570-2450 cal BC (SUERC-77444: 3971 25 BP, 25702410 cal BC), had been placed side by side at the base of one pit, directly opposite a large unworked flint nodule. Another pit in the group contained an apparently unused antler from which only the crown had been removed, along with two scrapers that were similarly placed together. This antler produced a radiocarbon date modelled as 2480 2370 cal BC (SUERC-77446: 3904 24 BP, 2470-2300 cal BC).

Two large circular features lay at the northern limits of the site. One, over $4.50 \mathrm{~m}$ in diameter, had a spread of material including animal bones, burnt flint and flint knapping debris (with microdebitage and refitting artefacts) across its base. The flaking debris was concentrated in the south-east quadrant where it may have resulted from controlled dumping or alternatively from in situ knapping. A pig mandible returned a date modelled as 2570-2450 cal BC (SUERC 77452: 3964 225 BP, 2570-2350 cal BC). The second feature was located approximately $64 \mathrm{~m}$ to the east of the first and was almost totally devoid of finds.

A post-pit was located a short way from this empty pit. It measured approximately $1.30 \mathrm{~m}$ in diameter and was $0.83 \mathrm{~m}$ deep, with a central post-pipe approximately $0.70 \mathrm{~m}$ across. Charcoal fragments from towards the base of the feature associated with fragments of burnt human and animal bone returned a radiocarbon date modelled as 2480-2370 cal 
$B C$ (UBA-36394: 3875 \pm 30 BP, 2470-2220 cal BC). The edges of the post-pit were lined with residual chalk rubble packing, well preserved on the north side but splayed outwards on the south, suggesting that the post may have been pulled out.

\subsection{Late Neolithic activity on Lark Hill}

At Larkhill, two ring ditches sat on the slopes above the coombe's eastern side (Figure 12). One, situated on the hilltop, consisted of a circular ditch with an average diameter of $11.50 \mathrm{~m}(10.60 \mathrm{~m}$ internally and $13.20 \mathrm{~m}$ externally). The ring ditch was probably not a ploughed-down or otherwise levelled bowl or bell barrow, as there were no indications of differential fills in the ditch to suggest either a large internal mound, an internal or external bank, or any combination of these. Small assemblages of struck and burnt flint and animal bone were recovered from the ditch, along with thirteen sherds of Early Neolithic pottery. These sherds seem entirely out of keeping with the ring ditch, and perhaps derive from an earlier feature on the hilltop, destroyed by the ring ditch.

A large irregular tree-throw hole was located in the ring ditch's interior. Other than nine pieces of struck flint and eight burnt flints, it was empty and had no stratigraphic relationship with any dateable features. It is possible that the ditch was constructed around a tree that stood in this spot.

A second ring ditch was approximately $50 \mathrm{~m}$ downslope to the south-west. It consisted of a circular ditch with an average diameter of - again - 11.50m (10.60m internally and $13.20 \mathrm{~m}$ externally). Again, the ring ditch should probably not be considered a plougheddown or otherwise levelled round barrow as there were no indications of any mound or bank or mortuary activity at this stage. It must, however, be noted that there had been extensive truncation of the site in antiquity, with up to $0.50 \mathrm{~m}$ of the upper portion of the ring ditch removed (D. Norcott pers. comm.).

A large quantity of material included over 1100 pieces of struck flint and more than 1500 burnt flints, dominating an assemblage that also contained fragments of animal bone and sherds of pottery, unevenly distributed around the circuit. Of the total pottery assemblage 43 sherds were positively assigned to the Late Neolithic while 11 had a broader Late Neolithic/Early Bronze Age date.

Interior features dated to the Early Bronze Age, and both ring ditches were encircled by posts, probably at this same time (below). Some Early Bronze Age features cut one of the two tree-throw holes in the area defined by the second ring ditch, adding credence to the suggestion that both were constructed around standing trees. 


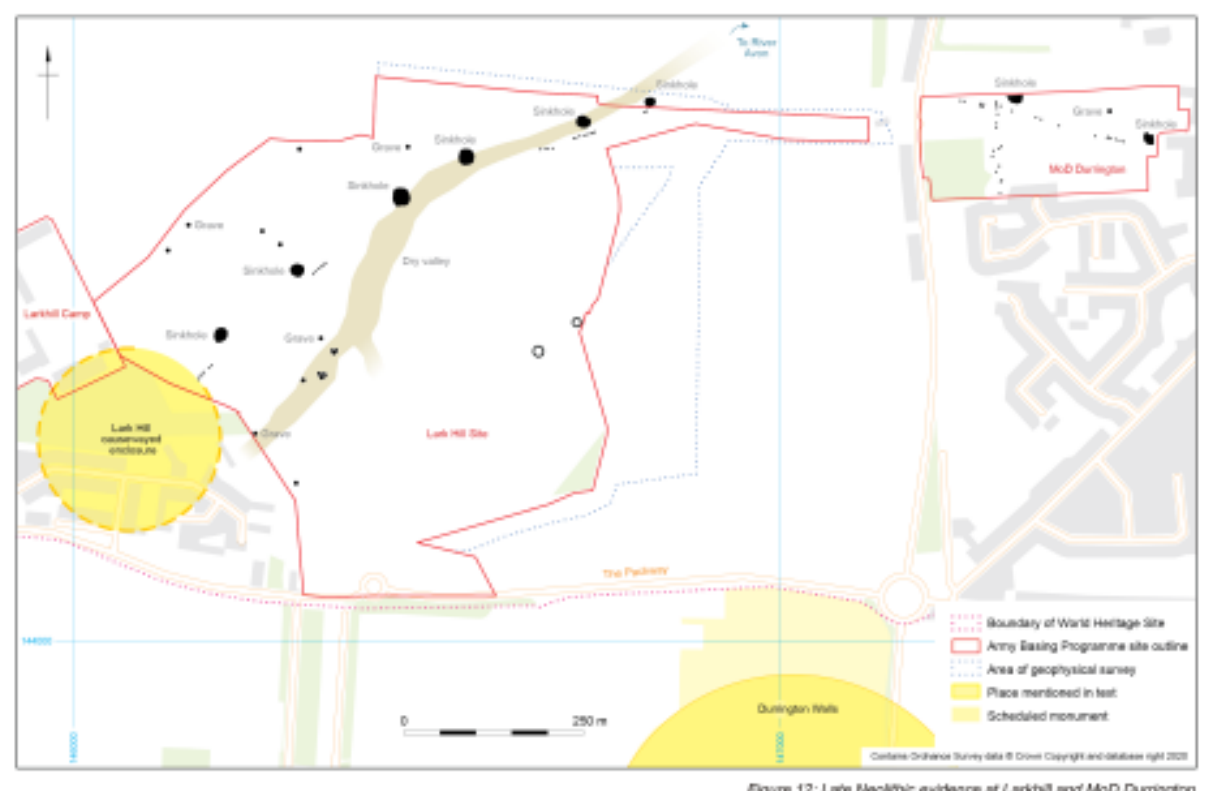

Figure 12: Late Neolithic evidence at Larkhill and MoD Durrington

Two isolated pits on the western side of the site date to this period based on their contents. One had a relatively large assemblage of material including struck flint, nearly 800 fragments of animal bone, 52 sherds of pottery (mostly Durrington Walls style Grooved Ware) and a little burnt flint. Its primary fill suggested that it had been left open to the elements long enough for weathering to take place before it was backfilled. The second pit, a little way to the north, contained an exceptional assemblage of 439 sherds of pottery (mostly Durrington Walls style Grooved Ware) and a large quantity of burnt flint (there was no record of other burnt material or ashy inclusions). It had been backfilled through episodes of deliberate deposition; no primary fill was identified.

\subsection{Solution hollows and post alignments}

Unlike the ring ditches, both of these pits lie outside the curving line of solution hollows forming the north-western arc of the 'massive pit structure' (Gaffney et al. 2020). The line of these solution hollows was marked at this same time by a row of 17 pits and posts (in three groups separated by unexcavated areas) standing inside the arc, running on a broadly east-north-east to west-south-west direction for some $260 \mathrm{~m}$ (exiting the excavated area at both ends). Two sorts of feature are represented: smaller examples, typically less than $0.5 \mathrm{~m}$ in plan and shallow (surviving to under $0.25 \mathrm{~m}$ deep) and larger features $0.8-1.4 \mathrm{~m}$ in plan and $0.85-1.25 \mathrm{~m}$ deep, some with larger lips interpreted as ramps for inserting posts. None of the shallower features showed any indication that they had held a post and were usually devoid of finds. The larger examples tended to have clear post-pipes and produced moderate to large assemblages of typically worked and burnt flint. Very little other material was recovered (a small quantity of apparently Late Neolithic pottery came from one of the postholes). 


\section{Solution hollows and post alignments at Durrington}

The post rows at Lark Hill are undated, but they appear to be a continuation of a row of 16 very similar features forming an alignment over $240 \mathrm{~m}$, identified in previous excavations at the former MoD Headquarters, Durrington (Thompson and Powell 2018)). There, a second line of seven postholes intersected at a tangent, running south for $40 \mathrm{~m}$ to the edge of excavation. From the two intersecting alignments, one of the postholes contained the charred remains of a post, some contained sapwood charcoal, and animal bone was recovered from others. Six contained Grooved Ware.

Modelling of the radiocarbon dates suggests that the rows - or parts of them - were constructed between 2745-2580 cal BC (85.9\%) at 95\% probability. Dates from animal bone in higher fills date the removal or rotting of the posts to before $2575-2470 \mathrm{cal} B C$ (at 95\% probability) (Thompson and Powell 2018), 108). A cremation burial in a shallow hollow was modelled as 2585-2460 cal BC (SUERC-49176: 4000 \pm 34 BP), contemporary with the infilling of the voids of the dismantled post alignment, and perhaps commemorating it.

This cremation burial is interesting for another reason. It lay in a shallow oval hollow on the line of the much larger solution features, covered with a deposit of over 2600 pieces of flint-knapping waste. The fills above contained more than 2700 pieces of struck flint. Although clearly anthropogenic, the pit seems to be located deliberately between two solution hollows, very much in the same way as the shallow oval pit in the entrance to the Lark Hill enclosure lies on the solution hollow line. At MoD Durrington, at least some of the solution hollows were the focus of contemporary deposition: in the western-most a flint gravel surface, possibly naturally accumulated around its outer edge, provided a platform on which knapping took place, predominantly on the feature's eastern side. Over 800 pieces were recovered, mostly unretouched debitage, in markedly better condition than the material filling the central and higher silting deposits.

\subsection{The Lark Hill post alignments}

A second row of six postholes at Lark Hill running south-west to north-east for over $30 \mathrm{~m}$ intersected with the north-western terminal of the south-eastern ditch segment of the causewayed enclosure, on the eastern side of its entrance. These features were mostly larger (only one less than $0.5 \mathrm{~m}$ diameter). One had a possible insertion ramp on its southern side.

It is assumed that these features held timber posts, with excavated chalk being used as packing material. Similar deposits of chalk were observed within the features, indicative of posts being removed and packing material slumping towards the base of the features creating near-horizontal deposits. No evidence of post-pipes was observed, suggesting withdrawal of posts rather than decay in situ; the upper fills appeared as a mix of topsoil and feature edge material.

Dates for this part of the row's construction are not available, but a fragment of a cattle atlas vertebra from one of the features gave a date of 2470-2300 BC (SUERC-70508, $3911 \pm 29 \mathrm{BP})$. This provides a terminus ante quem for the post removal, perhaps placing the activity somewhat later than at MoD Durrington. 
A further row of six postholes lie to the north-east, immediately north-east of a similarlyaligned Middle Bronze Age enclosure, with which it is possible they are associated. They lie, however, on the extrapolated line between the group cutting the causewayed enclosure ditch and the alignment to the north. All are small, approximately $0.5 \mathrm{~m}$ in diameter.

There is no indication at Lark Hill that these three separate groups of posts were ever connected: even taking into account the effects of truncation, nowhere among the various features revealed in the very large excavated area are there convincing candidates for further individual or grouped postholes that could belong to the same structure. It seems most likely, then, that the groups of posts were related, but discontinuous, running for various shorter or longer distances along parts of the interior of the arc formed by the solution hollows.

If these posts, together with those identified further to the south by Gaffney et al. (2020), all belong to a single discontinuous gigantic structure then they are of considerable interest. The only available date for the construction of such a truly monumental undertaking comes from MoD Durrington, at 2745-2580 cal BC. Why then does the arc they form appear to be centred on Durrington Walls? Even at the very youngest end of the distribution the posts pre-date the 'village' phase of activity there by some decades. The dates from MoD Durrington for the posts' removal, however, coincides rather comfortably with both the henges on the Bulford hilltop and either the 'village', the timber circle preceding the henge bank, or the Durrington Walls henge itself. It is tempting to suggest that the removed posts were recycled to Durrington Walls where they stood for no very great period before being taken down again as the henge was constructed.

Whatever the relationship between Durrington Walls and the post lines, it seems that the posts were decommissioned over a prolonged period, and in a variety of ways, with some extracted, others burnt and some left to rot.

One possible explanation for this is offered by the siting of the six posts cutting the causewayed enclosure's entrance. The row curves slightly, but measurements of azimuths of the group and various elements within it have demonstrated that the northeasternmost three posts have an end-to-end azimuth of $49.8^{\circ}$ and a best-fit azimuth for all three posts of $49.6^{\circ}$, close enough to the direction of the midsummer solstice sunrise over the shoulder of Sidbury Hill (between $49.1^{\circ}$ for the first gleam (upper limb) and $49.7^{\circ}$ for the centre) to show that the alignment is meaningful (Leivers et al. 2021). Assuming that the still-visible ditches defining the causewayed enclosure's entrance were not coincidentally chosen for the location of the post row, then the restatement of the (by now very old) solstitial alignment on Lark Hill may have meant that the posts survived here longer than in other parts of the structure.

\subsection{Beaker inhumations and other features}

The continued significance of this part of the post structure may be inferred from the presence at Larkhill of four graves (none yet dated by radiocarbon), two within and two beyond the solution hollow arc and post alignments.

Outside the circles, one grave contained what was believed to be an inhumation burial. Only seven teeth were recovered, from an infant of about one year of age accompanied by a Mid-Carinated Beaker. The second burial had suffered significant plough damage 
and was heavily disturbed, but the remains appeared to be of a possible female, 14-25 years old, accompanied by a Low-Carinated Beaker, smashed by the plough.

Those inside the ring were more remarkable. One was cut into the fill of a tree hollow with the skeleton positioned in the western half of the grave. The burial was of an adult male aged 35-55 years, in a flexed position. A grog-tempered Beaker was situated at the spine.

The second example inside the rings contained the skeletons of three children (Figure 13). The earliest, badly crushed, burial was of a 10-12 year old, aligned roughly eastwest lying on their right-hand side and very tightly crouched with the arms and legs pulled in to the body and the hands and knees up to the face. At the back of the head was a Plain Beaker.

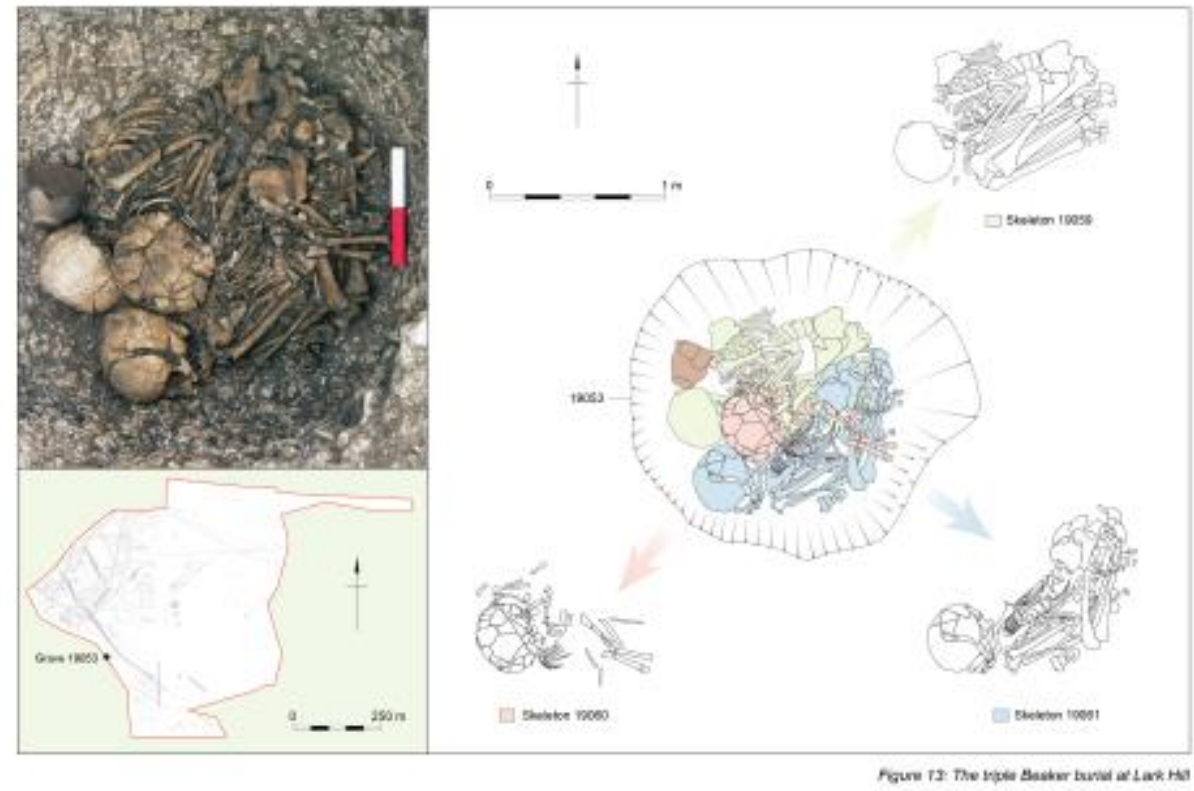

Figure 13: The triple Beaker burial at Lark Hill

Partially overlying this skeleton was a 9-11 year old, aligned roughly east-west, again tightly crouched on their right-hand side with the arms and legs pulled in and the hands up by the face. Overlying both were the heavily crushed remains of a 3-4 year old. The bones were very fragmentary, so position was difficult to interpret although it appears the individual was lying prone. It is unclear if the three individuals had been buried at the same time or if there was a hiatus between each burial.

The apparent differences in burial inside and outside the sinkhole arc and post alignments are, however, dispelled by Beaker inhumations within Larkhill Camp to the west, close to the Knighton long barrow. Here, two Beaker inhumations included a crouched 14-16 year old female, radiocarbon dated to between 2340 and 2140 BC and a pit containing the disarticulated (but in some semblance of anatomical order) remains of a 7-8 year old, the most notable feature of which was evidence for a small, wellhealed trephination in the centre of the frontal bone close to the coronal suture. The rarity of examples of this form of surgical procedure from the Bronze Age is enhanced in 
this instance by its having been performed (successfully) on a juvenile - this is perhaps a unique occurrence, since previously recorded Bronze Age examples, several from Wiltshire, are all on adults. Fragments of Beaker pottery along with worked flint, burnt flint, burnt animal bone, fragments of sarsen stone and a pierced stone bead were recovered from the backfill of the pit containing these bones.

Eleven pits at Lark Hill (one probably associated with four postholes) also dated to the Beaker period. All lay within the arcs of solution hollows and posts, with the exception of one, dated to this period based only on two fragments of Beaker. None is very securely dated, with the exception of one (associated with the postholes) containing 19 sherds of Beaker ceramics. Four other essentially undated pits cluster around it. A second small group of pits with little in the way of contents clustered around an example containing a modest assemblage including a flint knife and 22 sherds of Beaker pottery.

A large oval pit measuring $1.52 \mathrm{~m}$ deep lay at the western limits of excavation. Given its size, the assemblage recovered from it is modest. The one large pottery sherd from its fills was given a Late Neolithic/Early Bronze Age provenance while a red deer antler was radiocarbon dated to 2200-1950 BC (SUERC-79429, 3678 $\pm 40 \mathrm{BP}$ ). The stratigraphy with a primary deposit followed by a period of deliberate backfill shows that the pit was left open after its initial cutting before material was deliberately deposited in it. It was not completely backfilled, and it was left to silt up naturally.

\subsection{Beaker-period activity at Bulford}

At Bulford, evidence of activity in the Beaker period was limited, but unmistakeable. A sub-oval pit was filled with a band of compacted chalk rubble concentrated along the south side, thinning to the west and east. The central area, approximately $0.50 \mathrm{~m}$ square, was filled with chalk rubble mixed with brown silty loam that had collapsed through the lid of a box-like container into the original empty space in which had been placed a Beaker pot and a stone archer's wrist guard (Figure 14).

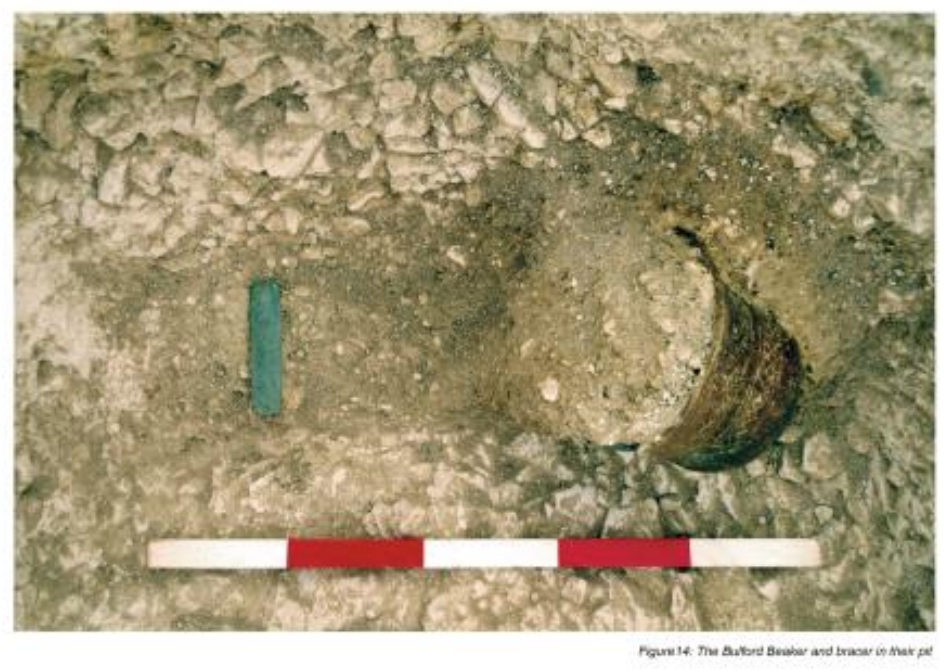

Figure 14: The Bulford Beaker and bracer in their pit 


\section{After Stonehenge - the Early Bronze Age (20th to 17th Centuries $\mathrm{BC})$}

\subsection{The Early Bronze Age at Bulford}

Continuous ring ditches encircled the two Late Neolithic henges at Bulford, enlarging the diameters to $27 \mathrm{~m}$ on the west and $30 \mathrm{~m}$ on the east (Figure 15). The two ditches intersect, but it was not possible to demonstrate priority in the excavated portion. The western example appears to have had a low internal bank or mound; on the east evidence was lacking. No burials or other internal features were found. The eastern ditch was dated by a fragment of red deer skull from a fine silt on the base to 1950-1760 cal BC (SUERC-78112: 3534 \pm 29 BP).

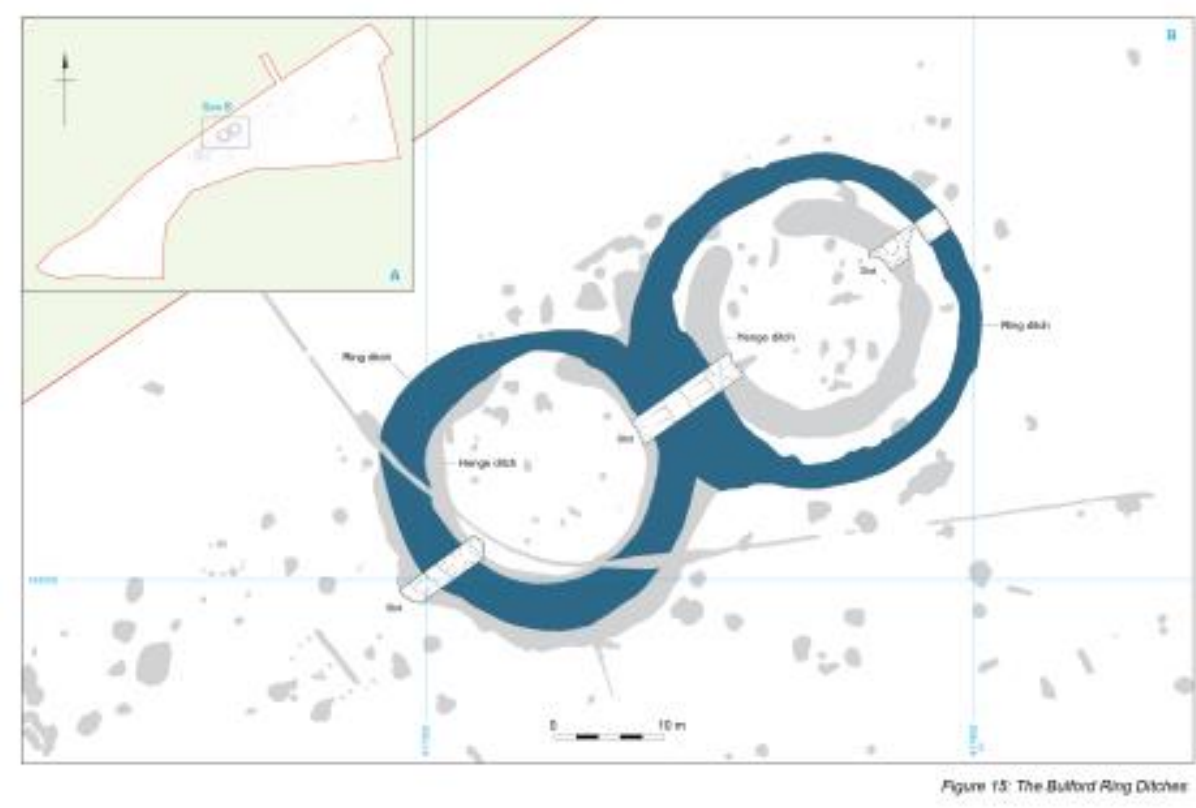

Figure 15: The Bulford Ring Ditches

Parallels for such conjoined ditches exist around Stonehenge: Amesbury 46 and 47 in the Cursus group, for instance (Bowden et al. 2015, 60). At Bulford these sites whatever their form may have been - sit in a much-inhabited area along the Nine Mile River, which contains one of the densest distributions of round barrows in the country, such that McOmish et al. have suggested that 'it would be plausible to see the Nine Mile River valley, itself, as a sacred entity' $(\underline{2002}, 50)$. 


\subsection{Early Bronze Age Lark Hill}

At Lark Hill (Figure 16), on the hilltop above the dry valley's eastern flank, a ring of 14 oval or sub-circular postholes surrounded the Late Neolithic ring ditch, approximately $0.50 \mathrm{~m}$ from its outer edge, between $0.45 \mathrm{~m}$ and $1.60 \mathrm{~m}$ apart. None produced dating evidence: the circle is provisionally dated to the Early Bronze Age owing to its similarities with a second post circle to the south-west.

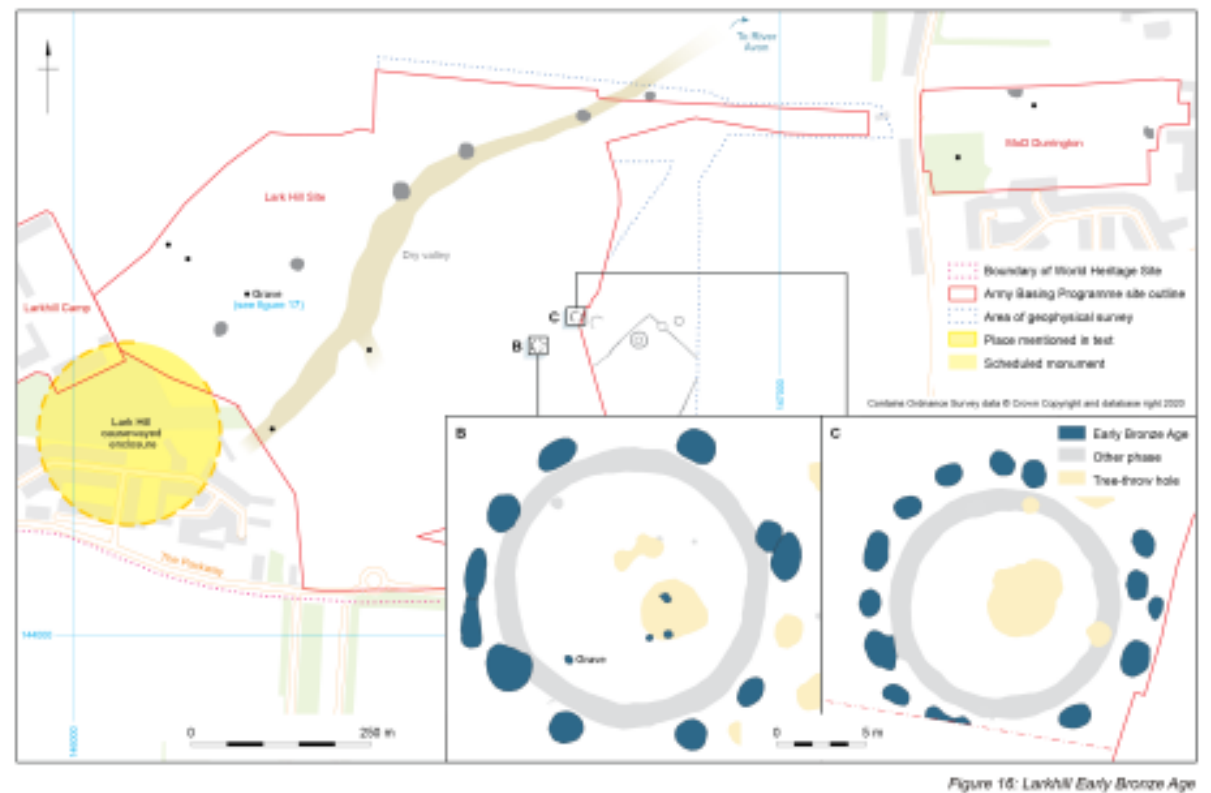

Figure 16: Larkhill Early Bronze Age

This second example consisted of 11 postholes, again surrounding a Late Neolithic ring ditch. Three of the postholes cut the ring ditch's upper fills, and it is probable considering the degree of truncation and the proximity of the postholes to the ditch - that several others originally cut the fills of the ditch.

Within the post circle were four features, three cutting a tree-throw hole. One (an unurned cremation deposit) contained burnt flints, two fragments of Bronze Age pottery, a fragment of stone and a metal bead and the remains of a 15-17 year old female accompanied by the cremated remains of a possible small canid. A fragment of human femur was radiocarbon dated and produced a date of 1740-1540 cal BC (SUERC$81889,3354 \pm 28 \mathrm{BP}$ ) placing it at the very end of the Early Bronze Age. A second feature may also have been an unurned cremation grave, containing four fragments of cremated human bone from a sub-adult/adult.

A third feature was a small, shallow pit containing a fragmented near-complete Food Vessel. No human remains were recovered to indicate that it had been a grave, but the condition of the pot showed that there had been truncation of the feature. Nearby was another small shallow feature whose function was unclear. The fill of the tree-throw cut by these features contained burnt flint. 
In plan, this pair of sites appear very similar to Amesbury 135 (Gaffney et al. 2018), both in size and morphology, with an inner ring ditch and outer post circle. Other examples are scarce, but the likelihood of multi-phase construction should be borne in mind, as should the possibility that these sites need never have been (or may not originally have been) barrows.

On the opposite side of the dry valley, a large sub circular posthole $2.20 \mathrm{~m}$ long by over $1.20 \mathrm{~m}$ wide and $1.67 \mathrm{~m}$ deep was located on the south-facing slope (Figure 17). The shallower concave eastern edge is interpreted as an insertion ramp for the erection of a large timber post. Its southern side had been destroyed by a World War 1 training trench.

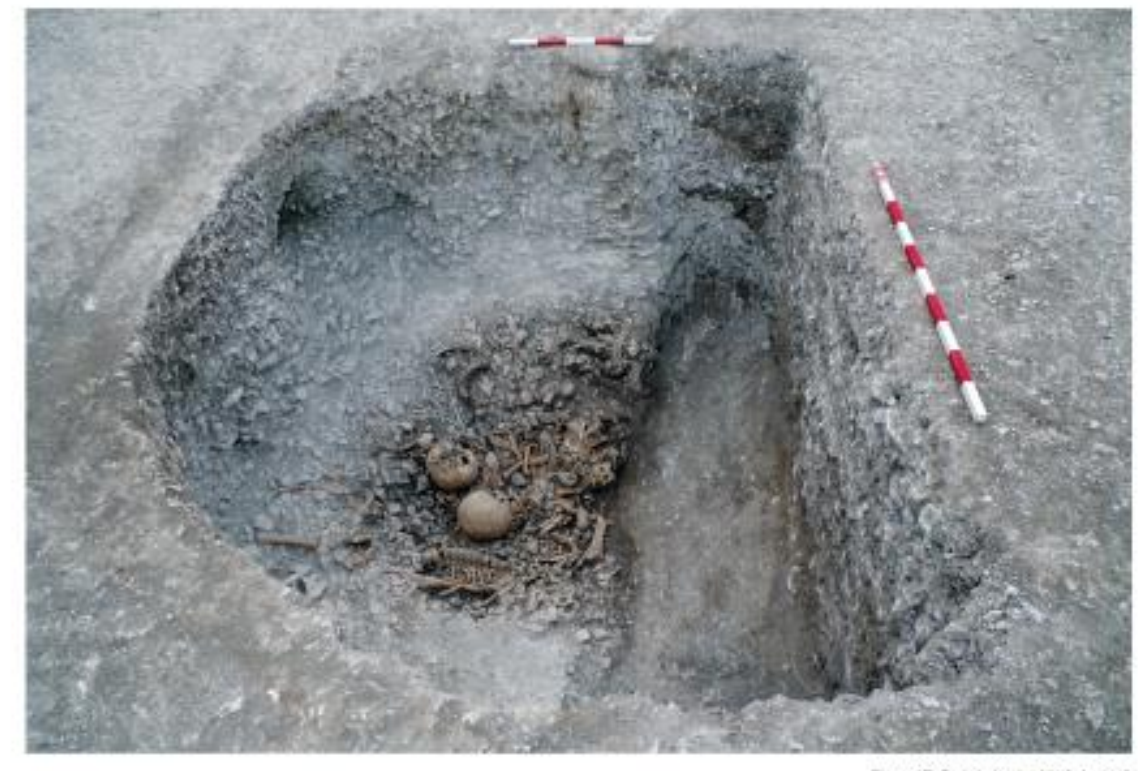

Figure 17: Burials in pit 18012, Larkhill

The disturbed chalk packing material lay below a weathering cone into which a collection of disarticulated animal bone and human remains were placed. The human remains included articulated and disarticulated bone, some of which exhibited cut marks, canid gnawing, and polishing, suggesting earlier exposure and manipulation elsewhere. At least three individuals were represented: an adult male 35-50 years of age; an adult female 18-25 years of age; and a possible female adult 25-35 years of age.

A sheep/goat left pelvis from one collection of animal bone was radiocarbon dated to 1880-1630 cal BC (SUERC-79428: 3428 \pm 39 BP). There is no convincing evidence to suggest how much time elapsed between the erection of the original post and the deposition of the human and animal remains.

A tree hollow downslope from the causewayed enclosure contained a small quantity of struck flint and animal bone and the fragmentary remains of a Collared Urn. All of the artefacts were restricted to the upper fill. A second Collared Urn was placed in the northwesternmost segment of the partially filled causewayed enclosure ditch. 


\section{Discussion}

\subsection{Towards a sequence of activity in the Early Neolithic}

The results of the Army Basing Programme allow the construction of a chronology of activity in the Stonehenge landscape that is both longer and somewhat different in tone to existing schemes. In summary (and putting aside the growing evidence of Mesolithic activity around the Avon, if not on the chalk, given the chronological gap between the two bodies of evidence), the sequence begins with:

- $\quad$ the Coneybury Anomaly, still probably the earliest dated evidence in the 38th century, but perhaps now only slightly earlier than or even contemporary with

- the Lark Hill causewayed enclosure, which could be as early as the first half of the 38th century, or as late at the middle of the 37th,

- followed by Robin Hood's Ball, and some of the dated long barrows seeming to fall into the 37th and 36th centuries, with both cursuses and more long barrows shortly thereafter along with (possibly) the Wilsford Shaft.

It is worth bearing in mind the limitations of the radiocarbon dates for the Early Neolithic. Few of the long barrows are directly dated; Robin Hood's Ball has very few dates, Lark Hill currently only a single determination. Many of the sites in question show evidence for alteration and re-use, sometimes for many centuries after their foundation. How the evidence of the various artefact scatters and pit groups fits into this chronology is somewhat opaque.

\subsection{The Middle Neolithic}

What is clear is the lacuna in construction during and after the 34th century, for at least 300 years. Given that the first phase of Stonehenge is contemporary with the first use of Grooved Ware ceramics, and consequently Late Neolithic, a Middle Neolithic phase of earth, stone and timber architecture typified by Peterborough Ware is - with the possible exception of the Normanton Down long mortuary enclosure - conspicuously absent.

The Middle Neolithic was, until recently, rare in the Stonehenge landscape: a pit group north of the Avenue, individual dispersed pits, small quantities of Peterborough Ware in artefact scatters, and some chisel arrowheads (and even these need not be Middle Neolithic, given the associations with Woodlands Grooved Ware). The radiocarbon date from pits in the coombe at Bulford appears to be Middle Neolithic, although the pottery consists of bowl forms (and not Ebbsfleet bowls). More recently, two sites have gone a good way towards clarifying the nature of Middle Neolithic inhabitation: at West Amesbury Farm and on the Army Basing Programme at Larkhill Camp. Both contained pit clusters of Middle Neolithic date.

At Larkhill, there is a clear shift in the preferred locations of activity in the Middle Neolithic (Figure 18). The area occupied by the causewayed enclosure and its immediate hinterland to the north and east were devoid of evidence of Middle Neolithic occupation, although there is no sense in which Early Neolithic sites were deliberately 
avoided: further to the west, higher up the slope in the area now occupied by Larkhill Camp, between the enclosure and the two Knighton barrows, there is good evidence for Middle Neolithic occupation.

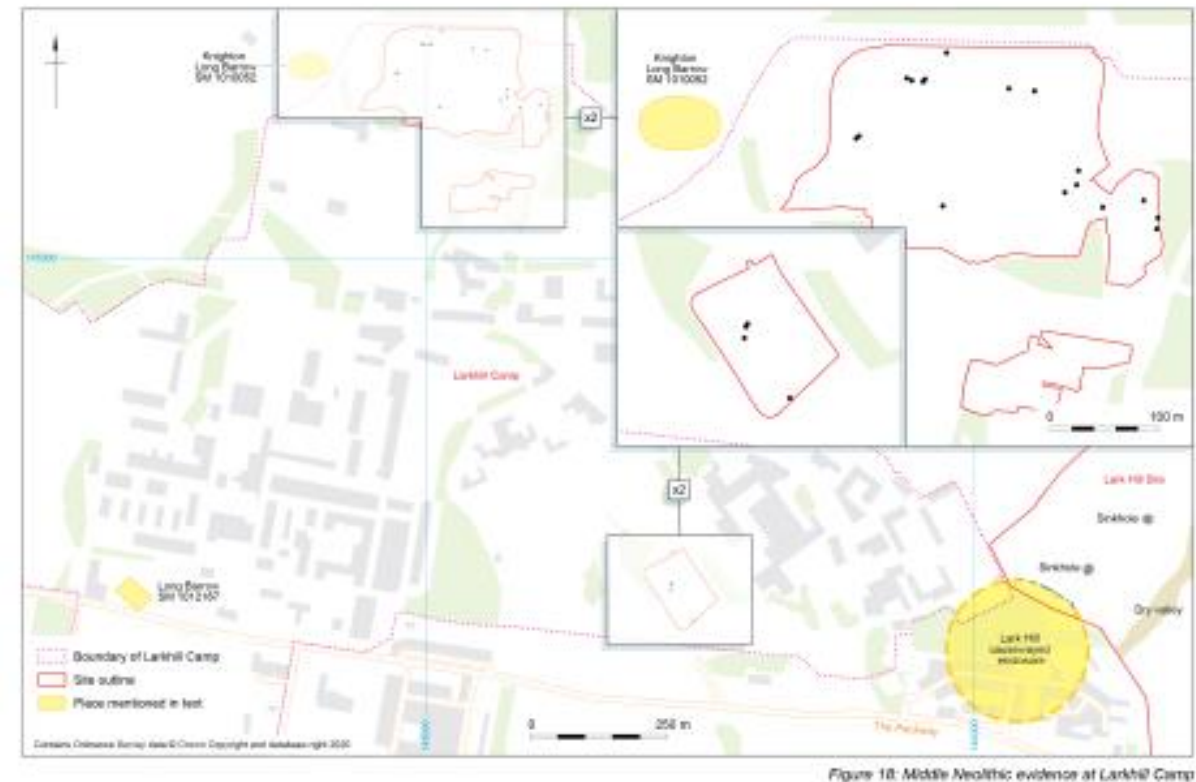

Figure 18: Middle Neolithic evidence at Larkhill Camp

In one area, between 200 and 400m east of the Knighton long barrow, 16 pits in widely spaced pairs or small groups were of Middle Neolithic date. Twelve of these contained Peterborough Ware pottery of the Ebbsfleet, Mortlake and Fengate types. In a second area, no more than $500 \mathrm{~m}$ west of the projected line of the causewayed enclosure, two pits contained Peterborough Ware pottery. One, $7 \mathrm{~m}$ to the south of a cluster of 12 pits, contained sherds of Mortlake type while a second pit in the cluster, which spread over a north-east to south-west aligned area $8 \mathrm{~m}$ long and $3 \mathrm{~m}$ wide, contained fragments of a single Ebbsfleet vessel. The pits varied in size and shape, most of them circular or subcircular, and all contained chalk-rich fills, with the evidence suggesting they had been rapidly backfilled.

At West Amesbury, Historic England encountered five Middle Neolithic pits and a burial, along with four postholes that may have been contemporary. Ceramic associations were predominantly of Fengate type, although some Mortlake was present. An astonishingly large flint assemblage (over eleven thousand pieces from the pits) included burins and 'mini rods' (Roberts et al. 2020), both more usually encountered in Mesolithic assemblages (although definitely Middle Neolithic here and elsewhere in the region). Other contents of the West Amesbury pits, such as undecorated chalk plaques and fossil beads, have similarities with the later groups of material recovered from the pits on the Bulford hilltop. Modelling of radiocarbon dates suggests that activity at West Amesbury began in 3370-3155 cal BC (94\%) or 3135-3120 cal BC (1\%) and ended in 3325-3310 cal BC (1\%) or 3295-3255 cal BC (4\%) or 3235-3060 cal BC (90\%). 


\subsection{The Late Neolithic}

There is no necessary gap between this Middle Neolithic activity and the Late Neolithic sequence, which begins somewhere around $3000 \mathrm{BC}$ with

- the Aubrey Holes, sitting somewhere around 3080-2890 cal BC,

- the Stonehenge ditch, at 2990-2755 cal BC, and

- the Woodlands pits at Bulford, modelled to perhaps $2950 \mathrm{cal} \mathrm{BC.}$

All of this activity could easily have taken place at much the same time. What this would mean is that users of Orcadian Woodlands Grooved Ware were erecting a stone circle made of rocks quarried in south Wales on a spot on Salisbury Plain.

\subsection{Why Stonehenge is where it is}

We come once again to the perennial questions of what and why? What is Stonehenge, and why is it where it is? The circle's location has often been considered 'undistinguished' (Cleal and Allen 1995, 37), and as Cleal and Allen note (1995, 40), intervisibility between the stones and the cursus does not seem to have been important in the siting of either. But, as we have seen, the relationship between the two clearly was of considerable importance, both in terms of their location and their meaning; so important, in fact, that direct visibility of the point where the sun sets into the cursus on midsummer was less important than Stonehenge being where it is. So why this particular spot?

The often-noted claim that there is nothing to distinguish that particular patch of downland from any other, and that it carries no particular topographic qualities (see, for instance, Cleal et al. 1995 for a discussion of views into and out of the circle) now needs revision, given the Stonehenge Riverside Project's discovery of geomorphological features underlying the Avenue (Allen et al. 2016), and while these low chalk ridges and periglacial stripes may have influenced Stonehenge's situation, they need not have determined it, especially given that the orientation of the first Stonehenge on the summer solstice is an approximate aspect rather than an exact orientation (if it even exists at all: Ruggles 1997). The GPR plot in Field et al. 2014 (9, fig. 7) implies that Stonehenge may sit on top of, rather than at the end of buried features trending broadly south-west/north-east. Nevertheless, the periglacial stripes and chalk ridges are intriguing, not least because they suggest another parallel between the locations of Stonehenge and the Lark Hill enclosure on linear arrangements of geological features with solstitial references. Newell's Mound provides another possible referent for Stonehenge's solstice aspect, and the trend of both the circle's original aspect and its altered precise alignment towards the midsummer sun's rising over Sidbury Hill, or rather what it coincides with along its way, provides one further possible clue to the reason for Stonehenge's location.

The Stonehenge Riverside Project's investigations along the solstice line on the top of Lark Hill revealed nothing convincing among the disturbances caused by the early 20thcentury military camp (Parker Pearson et al. 2005). Further to the north-east, a group of round barrows straddle the line, visible on aerial photographs and enclosed by a trapezoidal ditch (Figure 19), one recently tested during a watching brief on a water pipeline (Randall 2020). These are all almost certainly later than the establishment of the 
line from the Stonehenge circle at the start of the third millennium (leaving aside the possibility of an earlier marker within what became Stonehenge): the enclosure is undated and could be early, but it appears to run up to at least one of the barrows, suggesting an Early Bronze Age date at the very earliest.

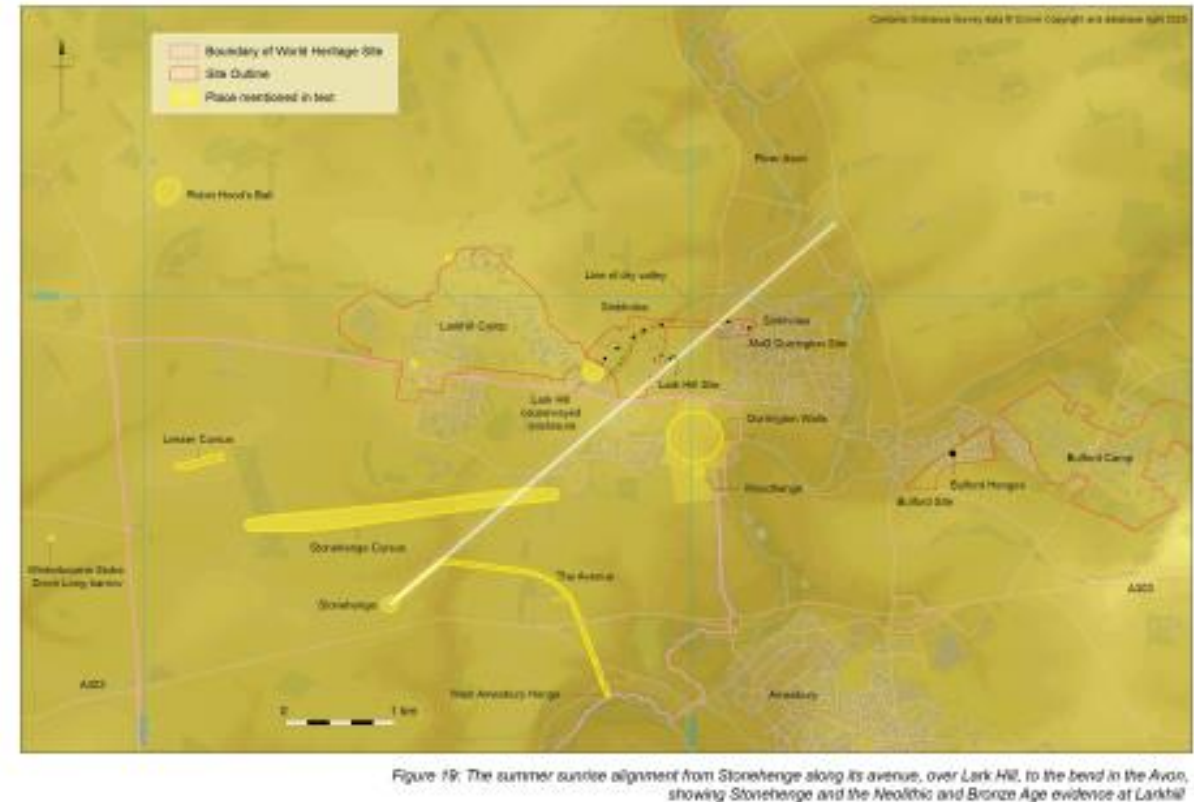

Figure 19: The summer sunrise alignment from Stonehenge along its avenue, over Lark Hill, to the bend in the Avon, showing Stonehenge, the Neolithic and Bronze Age evidence at Larkhill

Further to the north-east, the line cuts through the sinkhole arc tantalisingly close to feature 14D (Gaffney et al. 2020) - the feature at MoD Durrington with the flint 'metalling' and Late Neolithic knapping debris (Thompson and Powell 2018)). From here, it continues to bisect the large meander in the Avon from which the dry valley leads up to the Lark Hill causewayed enclosure. Darvill noted the significance of precisely this point on the Avon in his discussion of Stonehenge's 'sacred geography' (Darvill 1997, 179 and fig. 5). Could it be that the meander in the river maintained its significance over 700 years to such a degree that it influenced the location of Stonehenge?

\subsection{Objections to the model}

There is a venerable tradition of drawing lines on maps of the Stonehenge landscape and claiming all sorts of things on their basis. We need to apply a good degree of scepticism to any such scheme, including this one. The most obvious objection to the suggestions made here are that key elements are not intervisible - neither the bend in the Avon north-east of Lark Hill nor Sidbury Hill can be seen from Stonehenge and, conversely, Stonehenge cannot be seen from the bend in the Avon: the rising ground leading up to the Lark Hill ridge obscures the view. But this might perhaps be no objection at all: as suggested for the physically much closer relationship between the site of Stonehenge and the western end of the Stonehenge Cursus, the knowledge that these things were there, and important, could very easily have outweighed the need to 
be able to see one from the other. As Roberts et al. note, it is important to consider 'the affordances for visibility that may have arisen through movement around the landscape in the course of day-to-day activities, particularly following watercourses with livestock' (2020).

Are the difficulties of maintaining a line between invisible points over such a distance impossible? From the centre of Stonehenge to the Durrington Meander is $4.3 \mathrm{~km}$, but a series of markers (periglacial stripes, Newell's Mound, the large pit in the Cursus, etc.) could carry the line in a series of steps over intervening horizons.

That Stonehenge would have to have been quite a distance from its location for the solstice alignment to not cross the meander in the Avon is not necessarily an objection. We can distinguish between general solstitial aspects in the Early Neolithic and precise solstitial alignments only occurring later, at the end of the Late Neolithic, in the Stonehenge landscape at least, even if it is not the case elsewhere: the summer solstice sunrise alignment built into the Early Neolithic trapezoidal enclosure at Rectory Farm, Godmanchester, for instance, is 'impressive in its precision' (Ruggles 2019, 77). It seems more likely that a combination of features, mostly natural, some artificial, combined to place Stonehenge where it is, in a landscape already rich with meaning.

\subsection{Activity beyond Stonehenge}

Events in the four centuries after the construction of the Aubrey Holes and Stonehenge earthwork and the Bulford pits are somewhat obscure. That Stonehenge was in use as a cremation cemetery in this period is now well established (Darvill et al. 2012; Marshall et al. 2012; Willis et al. 2016). Elsewhere, inhabitation is difficult to detect. Coneybury Henge could have been constructed at this time, but is perhaps more likely to be somewhat later. It is possible that the lines of timber uprights standing within the arc of solution hollows north and east of Lark Hill originated in the 28th century, at least in part. Dates from MoD Durrington begin in this period, but this activity could be as late as the 26th century, only very slightly earlier than another major phase of building across the Stonehenge landscape. Other evidence includes the Chalk Plaque Pit, which has an even broader range of dates (see Davis et al. forthcoming for a reappraisal of the chalk plaques).

Regardless of their precise date, the lines of posts (or interrupted post circle) found in excavation at MoD Durrington and Larkhill, and suggested by geophysical survey southeast of Strangways, imply that by this date the 'massive pit structure' existed in some form, given that the posts are later than (and follow the line of) the solution hollows on Lark Hill and at MoD Durrington. It is worth considering what the features of this enormous arrangement might have been. At Larkhill and MoD Durrington, all of the investigated examples were natural in origin, but at both the line was interspersed by smaller anthropogenic features (of very different dates: one Early Neolithic in the entrance of the Lark Hill enclosure, one Late Neolithic and a focus for burial and deposition at MoD Durrington). What this suggests is that the arc of 'massive pits' need not have been of any one thing, or of any one date. While many of the examples in the northern half were ancient geological features related to the topography, the southern parts of the arc (or some of them) could have been created by hand, very much later, and not all at once. None the less, even one of these features would have been an enormous undertaking that poses any number of questions, including when, why, and (not least) what happened to the spoil? 


\subsection{Iconoclasm or continuity?}

The 26th and 25th centuries see the floruit of truly monumental construction in the Stonehenge landscape. This is the period in which the Trilithons and Sarsen Circle were erected; in which the henges at Bulford were built; of the Durrington Walls buildings, timber circle and henge; and the large post on the hilltop at Bulford. But it was also at least the start of the dismantling of the timber uprights within the arc of solution hollows, a process that may have taken two centuries or more to complete. Also dismantled in this same period of the 25th to 23 rd centuries was the bluestone circle on the banks of the Avon.

This period is also marked by the introduction of Beaker ceramics and culture, and possibly people. It is tempting to read the sequences of removal and rebuilding as an episode of iconoclasm, but there are indications of continuity across the period. The most obvious is Stonehenge itself, in which the primacy of the rising sun is made ever more apparent, but there are others. At Bulford, the animal bone assemblages in the Woodlands pits contain a number of significant elements, not least the remains of a large raptor. While definite confirmation of the identification remains to be achieved, it seems likely that the raptor was a white tailed (sea) eagle, a species also recovered from the ditch at Coneybury henge (Richards 1990). Dates for the Coneybury deposit place it slightly later than the Bulford pits, at around $2750 \mathrm{cal} \mathrm{BC}$, but intriguingly the same ditch deposits also contained the incomplete skeletal remains of a dog, which was also recovered from the ditch fills of the eastern henge at Bulford, and from postholes at Durrington Walls (Parker Pearson and Gaffney 2016). The deposition of elements of these same two species in ceremonial locations some $4.5 \mathrm{~km}$ apart over a period probably of some centuries indicates a shared and continued vocabulary of symbolic meanings previously only hinted at.

\subsection{What was Stonehenge?}

The other major trajectories of continuity are of course the solar and lunar alignments built into many of the sites in the region. Opinion is currently towards the midwinter sunset being the most significant of the Stonehenge alignments, mostly because processions into the circle along the Avenue are in that direction, and due to the differential dressing of sarsens (for instance Sims 2006; Ruggles 2009; but see Bowden et al. 2015, 45 - 'Stonehenge 2 is aligned on midsummer sunrise'). Neither is relevant to the initial phases of the site, and it is very much the case that it is midsummer aspects that are the focus of the ceremonial architecture of the fourth millennium. It need not be the case, of course, that multiple alignments were not (or could not become) significant, as is clearly the case with various solar and lunar references at Stonehenge and elsewhere.

The incorporation of general solstitial aspects and precise solstitial alignments into the ceremonial architecture of the area throughout the Neolithic, together with the timing of human activities taking place within them (as attested by, for instance, the age of pigs at slaughter at Durrington Walls (Wright et al. 2014)) indicate that - while these places were not calendars - they were calendrically-attuned. It seems beyond reasonable doubt that the gatherings that took place within, around or along the Lark Hill causewayed enclosure, the first Stonehenge and its cursus, the pre-henge Durrington Walls, Coneybury, Woodhenge and elsewhere did so at the points in the year which they 
referenced in their architecture. It seems that - by the Late Neolithic at least - the centrifugal pull of these places was strong enough to be felt very widely across various parts of the island of Great Britain (Viner et al. 2010; Madgwick et al. 2019), although the evidence suggests movements of livestock (and presumably people) from a number of specific locations, rather than from everywhere. The physical and conceptual links between Salisbury Plain and the Orcadian archipelago are increasingly apparent (although this does not imply the same for places between Wessex and Orkney). It may be no more than idle speculation to note the almost continual daylight of Orcadian summers, with only an extended twilight - the simmer dim - between sunset and sunrise, and the concomitant long hours of near darkness in winter. The midsummer sun aspects and alignments are what make Stonehenge and the ceremonial architecture surrounding it unusual - far more so than the architectural peculiarities of the stones themselves since most Neolithic and Bronze Age buildings that incorporate the sun into their architecture do so at midwinter (Bowden et al. 2015, 45). Perhaps then it was the fact that the builders of the Lark Hill enclosure had entered into a relationship with the rising midsummer sun that resulted in the Stonehenge landscape becoming the heart of the sacred landscape of Wessex in the Late Neolithic.

It is this relationship - between the sun, and people, and time - that lies at the heart of the ceremonial architecture of Salisbury Plain over some two millennia, continually stated and restated in ever more elaborate ways. And this, then, is what Stonehenge was - the articulation between the cosmic, sacred, otherworldly realm of the gods, spirits and the sun, and this world, the physical human world in which people lived and died, and which ensured that - despite everything - the two remained connected, and more than connected. Stonehenge - to borrow Alasdair Whittle's phrase - transcended time (Whittle 1997, 148). No matter what it might have looked like at any particular moment in its long and complex history of building, use and alteration, Stonehenge always claimed an understanding of and connection with the awesome nature of the otherworld, of the human place in it. It provided an assurance that - no matter how the seasons cycled and the skies darkened, no matter how the days shortened - there was a pattern and that people knew what it was. Within knowledge resides power: Stonehenge guaranteed that the sun would always come back. It was a grand assurance of life.

\section{Acknowledgements}

This research received no specific grant from any funding agency in the public, commercial, or not-for-profit sectors. It was supported by Wessex Archaeology as part of the Army Basing Programme.

In the preface to his novel The Great Captains, Henry Treece wrote that sooner or later all storytellers want to turn to Arthur. For the prehistorian living and working in Wessex, the same could be said for Stonehenge. I'm painfully aware that this article, my first attempt to give some shape to the results of 15 years of paddling around in the shallows of the subject, would have been impossible without the efforts of many other people, primarily my colleagues at Wessex Archaeology who did the majority of the hard work reported on here. I'm particularly grateful to Si Cleggett and Ruth Panes, who managed the outside and inside the wire elements of the Army Basing Programmes at Larkhill and Bulford respectively, and Steve Thompson, Pete Capps and Phil Harding, who directed the excavations there. Andy Manning managed the excavations at the former MoD Durrington, which were again directed by Steve Thompson. Steve and Phil, along with Andy Valdez-Tullett, wrote the bulk of the assessment reports for Bulford and Larkhill, 
and I have drawn on those heavily. They each have their own theories, not all of which align with mine, but which will hopefully reach print in the fullness of time. Richard Milwain produced the viewsheds, which were critical in shaping some of my arguments. Rob Goller's figures created clarity where there had been none.

I would like to extend my thanks to Erica Gittins, for reading and commenting on various drafts of this article, Amanda Chadburn and Clive Ruggles, who gently and persuasively led me away from numerous pitfalls, and Martin Gittins, for his perceptive comments on the Stonehenge Cursus. I've benefitted over the years from conversations with many other people working in the area. My debt to the Stonehenge Riverside Project and Stonehenge Hidden Landscapes teams is obvious, but I would particularly like to thank Josh Pollard and Vince Gaffney for discussing some of the ideas in this article with me. Bobby Gittins made sure that the language wasn't too opaque. My anonymous peer reviewers suggested many changes, and I am grateful to them. That I haven't always followed their advice is undoubtedly to my detriment, but their suggestions, along with the editor's patient assistance, resulted in a much better article than I initially submitted.

As the analysis of the results of the Army Basing Programme continues, and the results of other projects in the area reach publication, the details of the scheme outlined here will undoubtedly change. As Henry Treece also said, we're probably all wrong, but it makes a good story.

\section{Bibliography}

Allen, M.J. and Bayliss, A. 1995 'Appendix 2: The radiocarbon dating programme' in R.M.J. Cleal, K.E. Walker and R. Montague (eds) Stonehenge in its Landscape:

Twentieth Century Excavations, London: English Heritage. 511-

35. https://doi.org/10.5284/1028203/ https://archaeologydataservice.ac.uk/catalogue/ads data/arch-1416-1/dissemination/pdf/978-1850-746058 72.pdf

Allen, M., Chan, B., Cleal, R., French, C., Marshall, P., Pollard, J., Pullen, R., Richards, C., Ruggles, C., Robinson, D., Rylatt, J., Thomas, J., Welham, K. and Parker Pearson, M. 2016 'Stonehenge's Avenue and "Bluestonehenge"', Antiquity 90, 991-

1008. https://doi.org/10.15184/aqy.2016.98

Atkinson, R.J.C. 1979 Stonehenge, Harmondsworth: Pelican.

Barclay, A.J., Bayliss, A., Bronk Ramsey, C., Cleal, R., Cook, G., Healy F., Higbee, L., Marshall, P., Pelling R. and Stevens, C.J. 2018 Dating the Earliest Neolithic Ceramics of Wessex, Portsmouth: Historic England Research Report Series 63-2018.

Barrett, J., Bradley, R. and Green, M. 1991 Landscape, Monuments and Society. The prehistory of Cranbourne Chase, Cambridge: University

Press. https://doi.org/10.1017/CBO9780511735578 
Batchelor, D. 1997 'Mapping the Stonehenge World Heritage Site' in B. Cunliffe and C. Renfrew (eds) Science and Stonehenge, Proceedings of the British Academy 92, 6172. http://publications.thebritishacademy.ac.uk/pubs/proc/volumes/pba92.html

Bowden, M., Soutar, S., Field, D. and Barber, M. 2015 The Stonehenge Landscape. Analysing the Stonehenge World Heritage Site, Swindon: Historic England.

Brown, M. and Thompson, S. 2018 "'A matter of holes and ditches": the archaeology of Great War training, Larkhill, Wiltshire', The Wiltshire Archaeological and Natural History Magazine 111, 6-20.

Burl, A. 2006 Stonehenge: A History of the World's Greatest Stone Circle, London: Constable.

Chaffey, G. and Brook, E. 2012 'Domesticity in the Neolithic: excavations at Kingsmead Quarry, Horton, Berkshire' in H. Anderson-Whymark and J. Thomas (eds) Regional Perspectives on Neolithic Pit Deposition: Beyond the Mundane, Oxford: Oxbow Books [Neolithic Studies Group Seminar Papers 12]. 200-

215. https://doi.org/10.2307/j.ctvh1dkr0.19

Cleal, R.M.J. and Allen, M.J. 1995 'The visual envelope' in R.M.J. Cleal, K.E. Walker and R. Montague (eds) Stonehenge in its Landscape: Twentieth Century Excavations, London: English Heritage, 34-

40. https://doi.org/10.5284/1028203/ https://archaeologydataservice.ac.uk/catalogue/ads data/arch-1416-1/dissemination/pdf/978-1850-746058 72.pdf

Cleal, R.M.J., Walker, K.E. and Montague, R. 1995 Stonehenge in its Landscape: Twentieth Century Excavations, London: English Heritage. https://doi.org/10.5284/1028203/ https://archaeologydataservice.ac.uk/catalog ue/adsdata/arch-1416-1/dissemination/pdf/978-1850-746058 72.pdf

Darvill, T. 1997 'Ever increasing circles: the sacred geographies of Stonehenge and its landscape' in B. Cunliffe and C. Renfrew (eds) Science and Stonehenge, Proceedings of the British Academy 92, 167-

202. http://publications.thebritishacademy.ac.uk/pubs/proc/volumes/pba92.html

Darvill, T., Marshall, P., Parker Pearson, M. and Wainwright, G. 2012 'Stonehenge remodelled', Antiquity 86, 1021-40. https://doi.org/10.1017/S0003598X00048225

Davis, B., Harding, P. and Leivers, M. forthcoming 'New ways to view old objects using photographic techniques to study Neolithic chalk plaques'.

Exon, S., Gaffney, V.L., Woodward, A. and Yorston, R. 2000 Stonehenge Landscapes: Journeys through real-and-imagined worlds, Oxford: Archaeopress.

Field, D., Linford, N., Barber, M., Anderson-Whymark, H., Bowden, M., Topping, P. and Linford, P. 2014 'Analytical surveys of Stonehenge and its immediate environs, 20092013: Part 1 - the landscape and earthworks', Proceedings of the Prehistoric Society 80 , 1-32. https://doi.org/10.1017/ppr.2014.6

Gaffney, C., Gaffney, V., Neubauer, W., Baldwin, E., Chapman, H., Garwood, P., Moulden, H., Sparrow, T., Bates, R., Löcker, K., Hinterleitner, A., Trinks, I., Nau, E., Zitz, 
T., Flöry, S., Verhoeven, G. and Doneus, M. 2012 'The Stonehenge Hidden Landscapes Project', Archaeological Prospection 19(2), 147-55. https://doi.org/10.1002/arp.1422

Gaffney, V., Neubauer, W., Garwood, P., Gaffney, C., Löcker, K., Bates, R., De Smedt, P., Baldwin, E., Chapman, H., Hinterleitner, A., Wallner, M., Nau, E., Filzwieser, R., Kainz, J., Trausmuth, T., Schneidhofer, P., Zotti, G., Lugmayer, A., Trinks, I. and Corkum, A. 2018 'Durrington Walls and the Stonehenge Hidden Landscape Project 2010-2016', Archaeological Prospection 25(3), 1-15. https://doi.org/10.1002/arp.1707

Gaffney, V., Baldwin, E., Bates, M., Bates, C.R., Gaffney, C., Hamilton, D., Kinnaird, T., Neubauer, W., Yorston, R., Allaby, R., Chapman, H., Garwood, P., Löcker, K., Hinterleitner, A., Sparrow, T., Trinks, I., Wallner, M. and Leivers, M. 2020 'A massive, Late Neolithic pit structure associated with Durrington Walls Henge', Internet Archaeology 55. https://doi.org/10.11141/ia.55.4

Garrow, D., Lucy, S. and Gibson, D. 2006 Excavations at Kilverstone, Norfolk: an Episodic Landscape History: Neolithic Pits, Later Prehistoric, Roman and Anglo-Saxon Occupation, and Later Activity, Cambridge: East Anglian Archaeology 113. http://eaareports.org.uk/publication/report113/

Leivers, M. 2017a 'Robin Hood's other ball? A newly-discovered causewayed enclosure at Larkhill, Wiltshire', PAST 85,

12-13. http://www.prehistoricsociety.org/publications/publication/past 85 april 2017/

Leivers, M. 2017b 'The Army Basing Programme: new discoveries at Larkhill and Bulford', Historic England Research 6, 36-40. https://historicengland.org.uk/imagesbooks/publications/historic-england-research-6/he-research-6/

Leivers, M., Ruggles, C. and Chadburn, A. 2021 'A new midsummer alignment near Stonehenge', British Archaeology 176, 8-9.

Madgwick, R., Lamb, A.L., Sloane, H., Nederbragt, A.J., Albarella, U., Parker Pearson, M. and Evans, J.A. 2019 'Multi-isotope analysis reveals that feasts in the Stonehenge environs and across Wessex drew people and animals from throughout Britain', Science Advances 5, https://doi.org/10.1126/sciadv.aau6078

Marshall, P., Darvill, T., Parker Pearson, M. and Wainwright, G. 2012 Stonehenge, Amesbury, Wiltshire: chronological modelling, English Heritage Research Report 1/2012. https://research.historicengland.org.uk/Report.aspx?i=15075

McOmish, D., Field, D. and Brown, G. 2002 The Field Archaeology of the Salisbury Plain Training Area, Swindon: English

Heritage. https://doi.org/10.5284/1028203 / https://archaeologydataservice.ac.uk/catalog ue/adsdata/arch-1416-1/dissemination/pdf/9781848021501 all.pdf

Parker Pearson, M. 2012 Stonehenge: Exploring the Greatest Stone Age Mystery, London: Simon \& Schuster.

Parker Pearson, M. and Gaffney, V. 2016 'Ground-truthing Durrington Walls', British Archaeology 151, 26-31. 
Parker Pearson, M., Richards, C., Allen, M.A.J., Payne, A. and Welham, K. 2004 'The Stonehenge Riverside project: research design and initial results', Journal of Nordic Archaeological Science 14, 45-

60. https://www.archaeology.su.se/english/publications/publication-series/jonas/jonas-14

Parker Pearson, M., Pollard, J., Tilley, C., Thomas, J., Richards, C. and Welham, K. 2005 'The Stonehenge Riverside Project Summary Interim Report 2005', Unpublished report, University of Sheffield.

Parker Pearson, M., Allen, M., Pollard, J., Richards, C., Robinson, D., Thomas, J., Welham, K. and Wickstead, H. 2007a 'The Stonehenge Riverside Project 2007: Full Interim Report', Unpublished report, University of Sheffield.

Parker Pearson, M., Cleal, R., Marshall, P., Needham, S., Pollard, J., Richards, C., Ruggles, C., Sheridan, A., Thomas, J., Tilley, C., Welham, K., Chamberlain, A., Chenery, C., Evans, J., Knusel, C., Linford, N., Martin, L., Montgomery, J., Payne, A., Richards, M. 2007b 'The age of Stonehenge', Antiquity 81, 617-

39. https://doi.org/10.1017/S0003598X00095624

Parker Pearson, M., Allen, M., Bayer, O., Caswell., C., Chan, B., French, C, Garwood, P., Nunn, R., Pitts, M. Pollard, J., Pullen, B., Richards, C., Richards, J., Robinson, D., Rylatt, J., Shaw, D., Teather, A. and Thomas, J. 2008 'Stonehenge Riverside Project 2008 Interim Report', Unpublished report, University of Sheffield.

Parker Pearson, M., Pollard, J., Richards, C., Thomas, J., Tilley, C. and Welham, K. 2020 Stonehenge for the Ancestors Part 1: Landscape and Monuments, Leiden: Sidestone Press.

Pitts, M. 2012 Stonehenge in Five Easy Stages (Or Perhaps

Six) https://mikepitts.wordpress.com/2012/12/01/Stonehenge-in-five-easy-stages-orperhaps-six/

Powell, A.B. and Legg, S. 2020 'An Early Bronze Age "log burial" and other features along the Bulford to Tidworth cable trench, Defence Training Estate Salisbury Plain, 2017', Wiltshire Archaeological and Natural History Magazine 113, 56-84.

Randall, C. 2020 'A new barrow near Larkhill', Wiltshire Archaeological and Natural History Magazine 113, 273-8.

Richards, C., Jones, A., MacSween, A., Sheridan, A., Dunbar, E., Reimer, P., Bayliss, A., Griffiths, S. and Whittle, A. 2016 'Settlement duration and materiality: formal chronological models for the development of Barnhouse, a Grooved Ware settlement in Orkney', Proceedings of the Prehistoric Society 82, 193-

225. https://doi.org/10.1017/ppr.2016.6

Richards, J. 1990 The Stonehenge Environs Project, London: HBMC.

Roberts, D., Valdez-Tullett, A., Marshall, P., Last, J., Oswald, A., Barclay, A., Bishop, B., Dunbar, E., Forward, A., Law, M., Linford, N., Linford, P., López-Dóriga, I., Manning, A., Payne, A., Pelling, R., Powell, A., Reimer, P., Russell, M., Small, F., Soutar, S., Vallender, J., Winter, E. and Worley, F. 2018 'Recent Investigations at two long barrows 
and Reflections on their context in the Stonehenge World Heritage Site and environs', Internet Archaeology 47. https://doi.org/10.11141/ia.47.7

Roberts, D., Barclay, A., Bishop, B., Bronk-Ramsey, C., Campbell, G., Canti, M., Dobie, J., Dunbar, E., Dunne, J., Evershed, R. P., Forward, A., Last, J., Lamb, S., Linford, N., Linford, P., Linscott, B., Madgwick, R., Marshall, P., Mays, S., McParland, H., Payne, A., Pelling, R., Pike, A., Price, K., Quinn, P., Radini, A., Reimer, P., Russell, M., Seager Smith, R., Soutar, S., Speller, C., Vallender, J., Valdez-Tullett, A., Van Heekeren, V. and Worley, F. 2020 'Middle Neolithic pits and a burial at West Amesbury, Wiltshire', Archaeological Journal, https://doi.org/10.1080/00665983.2020.1758495

Ruggles, C. 1997 'Astronomy and Stonehenge' in B. Cunliffe and C. Renfrew (eds) Science and Stonehenge, Proceedings of the British Academy 92, 20329. http://publications.thebritishacademy.ac.uk/pubs/proc/volumes/pba92.html

Ruggles, C. 2009 Stonehenge and Ancient Astronomy, London: Royal Astronomical Society.

Ruggles, C. 2019 'Ill. Archaeoastronomy' in A. Lyons Rectory Farm, Godmanchester, Cambridgeshire: Excavations 188-95, Neolithic monument to Roman villa farm, Cambridge: Oxford Archaeology East [= East Anglian Archaeology Report No. 170], 4580. http://eaareports.org.uk/publication/report170/

Schmidt, A. and Crabb, N. 2017 'Larkhill SFA Haul Road, Larkhill, Wiltshire - Detailed Gradiometer Survey Report', Unpublished report: Wessex Archaeology.

Sims, L.D. 2006 'The "Solarization" of the moon: manipulated knowledge at Stonehenge', Cambridge Archaeological Journal 16(2), 191-

207. https://doi.org/10.1017/S0959774306000114

Thomas, J., Marshall, P., Parker Pearson, M., Pollard, J., Richards C., Tilley, C. and Welham, K. 2009 'The date of the Stonehenge Cursus'. Antiquity 83, 40-

53. https://doi.org/10.1017/S0003598X00098070

Thompson, S. and Powell, A.B. 2018 Along Prehistoric Lines: Neolithic, Iron Age and Romano-British activity at the former MOD Headquarters, Durrington, Wiltshire, Salisbury: Wessex Archaeology.

Viner, S., Evans, J., Albarella, U. and Parker Pearson, M. 2010 'Cattle mobility in prehistoric Britain: strontium isotope analysis of cattle teeth from Durrington Walls (Wiltshire, Britain)', Journal of Archaeological Science 37, 2812-

20. https://doi.org/10.1016/j.jas.2010.06.017

Walker, K.E. 1995 'History and methods of the principal excavations' in R.M.J. Cleal, K.E. Walker and R. Montague (eds) Stonehenge in its Landscape: Twentieth Century Excavations, London: English Heritage. 9-

16. https://doi.org/10.5284/1028203/ https://archaeologydataservice.ac.uk/catalogue/ads data/arch-1416-1/dissemination/pdf/978-1850-746058 72.pdf

Wessex Archaeology 2001 'Proposed woodland planting at "C" Crossing, Salisbury Plain Training Area, Wiltshire Archaeological Evaluation Report', Unpublished report ref. 49262.01. 
Whittle, A. 1997 'Remembered and imagined belongings: Stonehenge and its traditions and structures of meaning' in B. Cunliffe and C. Renfrew (eds) Science and Stonehenge, Proceedings of the British Academy 92. 145-

66. http://publications.thebritishacademy.ac.uk/pubs/proc/volumes/pba92.html

Willis, C., Marshall, P., McKinley, J., Pitts, M., Pollard, J., Richards, C., Richards, J., Thomas, J, Waldron, T., Welham, K. and Parker Pearson, M. 2016 'The dead of Stonehenge', Antiquity 90, 337-356. https://doi.org/10.15184/aqy.2016.26

Wright, E., Viner-Daniels, S., Parker Pearson, M. and Albarella, U. 2014 'Age and season of pig slaughter at Late Neolithic Durrington Walls (Wiltshire, UK) as detected through a new system for recording tooth wear', Journal of Archaeological Science $\mathbf{5 2}$, 497-514. https://doi.org/10.1016/j.jas.2014.09.009 